By

\author{
Chante Barnwell \\ Honours Bachelor of Arts, \\ University of Toronto, 2014
}

\author{
A Major Research Paper (MRP) \\ presented to Ryerson University \\ in partial fulfillment of the \\ requirements for the degree of \\ Master of Fine Arts \\ in the program of \\ Documentary Media
}

Toronto, Ontario, Canada, 2018

(C) Chante Barnwell, 2018 


\section{AUTHOR'S DECLARATION FOR ELECTRONIC SUBMISSION OF AN MRP}

I hereby declare that I am the sole author of this MRP. This is a true copy of the MRP, including any required final revisions.

I authorize Ryerson University to lend this MRP to other institutions or individuals for the purpose of scholarly research.

I further authorize Ryerson University to reproduce this MRP by photocopying or by other means, in total or in part, at the request of other institutions or individuals for the purpose of scholarly research.

I understand that my MRP may be made electronically available to the public. 


\title{
QUEEN OF THE BANDS: CARNIVAL AND "MONARCHY” IN THE (416)
}

\author{
Chante Barnwell, 2018 \\ Master of Fine Arts \\ Documentary Media \\ Ryerson University
}

\begin{abstract}
Queen of the Bands: Carnival and "Monarchy" in the (416) is a solo multimedia gallery installation which explores the complexity of Queenliness through the audio and photographic documentation of four women who perform as the head female masqueraders within the complex political framework of Toronto Caribbean Carnival's 2017 King and Queen competition. The Canadian national narrative reserves Queenliness for historically dominant European figures such as the Queen of England, so what does it mean to be a woman of colour performing as a queen in a Canadian carnival celebration? The complexity of this history and the prominence of African masking traditions in carnival Mas' making, among other cultural influences in the Caribbean, contribute to the notion of Queenliness within the framework of carnival.

The purpose of my photographic investigation is both to capture a tangible element of carnival's relationship to Emancipation Day history in Toronto and, among other things, to examine the women's representation and power in Afro-Caribbean communal celebrations. My additional objectives were the following: First, to evaluate how the historical framework of Emancipation Day in Ontario has shaped the current production of these celebrations in Toronto. Second, to contextualize the head female masquerader's position within the historical framework of emancipation and carnival. Third, to determine the role carnival celebrations play in defining a racialized woman's identity in Canadian society. Fourth, to investigate how employing documentary photography practices can shape the understanding of Emancipation Day and
\end{abstract}


contextualize African Canadian history. Lastly, to investigate the effect British monarchal representation in Canada has on Queenliness when performed by women of colour. 


\section{ACKNOWLEDGEMENTS}

First, I would like to thank God for blessing me on this journey. Persistence and perseverance have been placed in my steps, and I have been graced with the opportunity to follow my path. I can attest that I have been restored by faith and renewed by purpose.

To my mom, Mrs. Faye W. Barnwell, I love you so much; you have always been my number one supporter and defender. Since the beginning of my scholarly journey, you have always encouraged me to meet my full potential. I have been blessed with the opportunity to share this creative time with you. This MRP would not have been possible without your continuous love and support, and for that, I am forever grateful.

To my dad, I know you are amongst the angels in heaven smiling down on me. I wish you were here to see me cross the stage to receive my Master of Fine Arts degree in Documentary Media, but I know you're always with me.

To the Toronto Caribbean Carnival Community, all of you make the carnival what it is, and you truly live to respect the Mas'. Your ability to uphold the richness of our culture, transform the mundane into the extraordinary, work hard for hours on end, fête, get up early, go to sleep late, and compete for the glory of winning band of the year is amazing.

To the four Queens of the Bands, the main participants of my creative journey, Michelle Reyes, Emilsa Sealy, Deidra Amow and Ayanna Lee-Rivears and their respective Mas' bandleaders Louis Saldenah, Jerrol Augustine, Dwayne Gunness, Hayden Joseph and Aneil Persad. Thank you for your participation in my scholarly endeavours. Your dedication to creating and preserving the splendour of Big Mas' is a gift to Toronto's art and culture sector.

To my supervisor, Pierre Tremblay, advisor Bruno Lessard, and the Documentary Media faculty thank you for your commitment to my Master's Research Project and support paper. 
To future scholars of African Canadian and Caribbean Canadian history, it is increasingly necessary to pave a path that aids in the uncovering of histories that have been devalued, disregarded, and erased, so that the experiences of all, especially those of the African Canadian and Caribbean Canadian community, can be counted as worthy within the systems that continuously try to silence them. 


\section{DEDICATION}

This paper is dedicated to all the strong women in my family, past and present. 


\section{TABLE OF CONTENTS}

AUTHOR'S DECLARATION FOR ELECTRONIC SUBMISSION OF AN MRP ......................ii

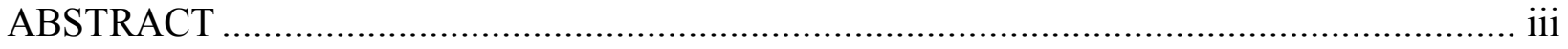

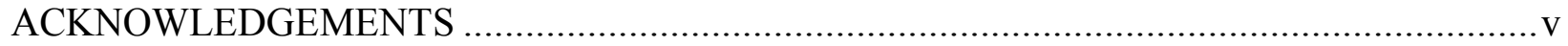

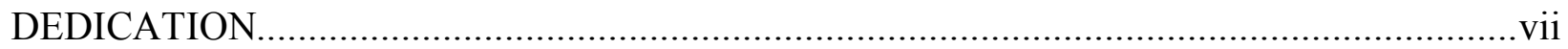

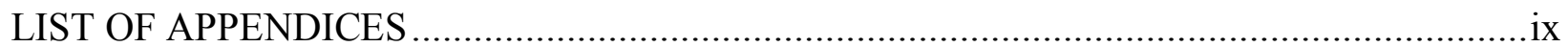

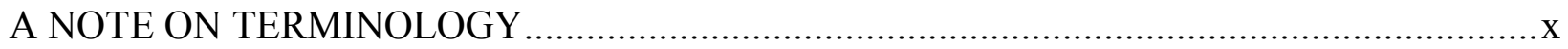

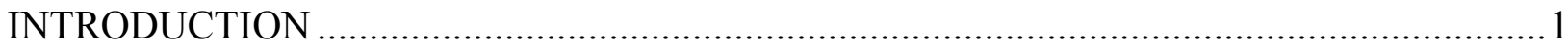

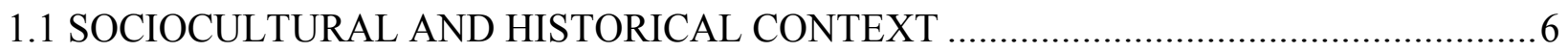

1.1.1-Emancipation Day in Toronto: A Display of Communal Consciousness ..........................6

1.1.2-Will the "Citizens" Please Rise: Commonwealth Identity in Canada ............................. 17

1.1.3-A Centennial Gift Turns Gold: Toronto Caribbean Carnival at Fifty............................. 19

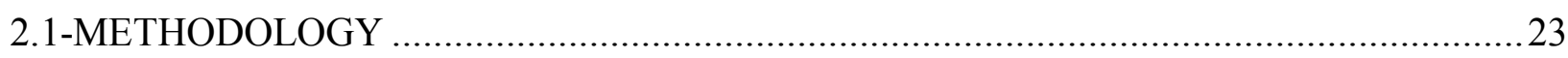

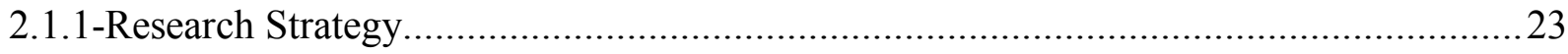

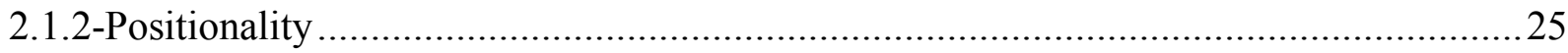

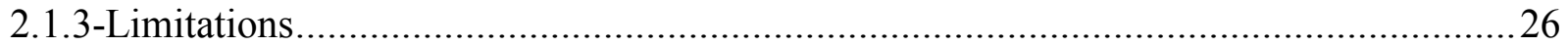

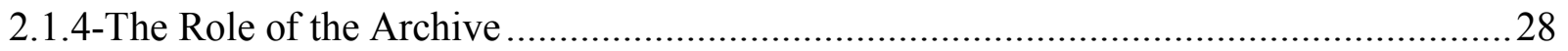

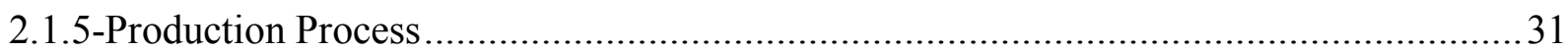

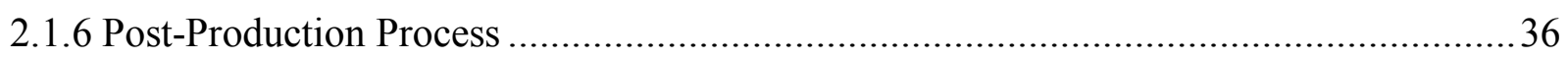

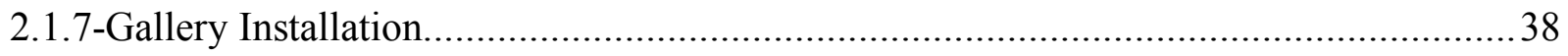

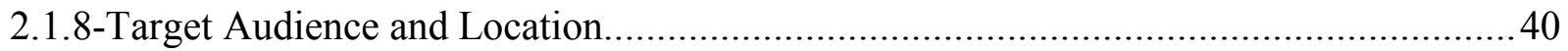

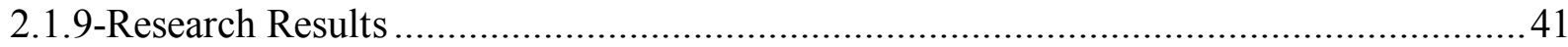

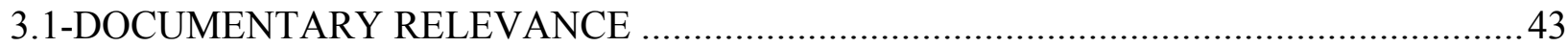

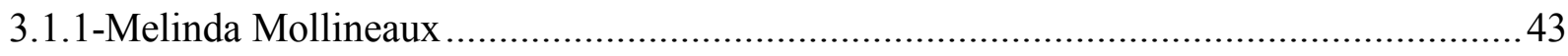

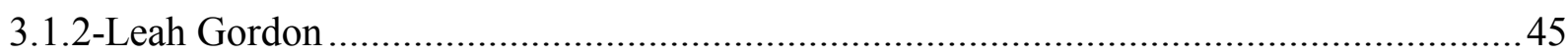

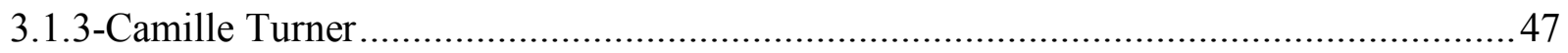

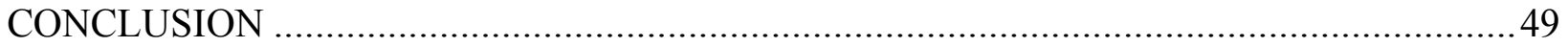

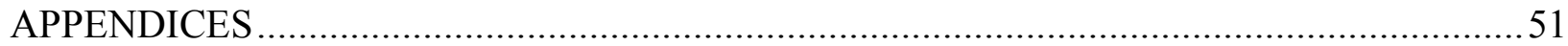

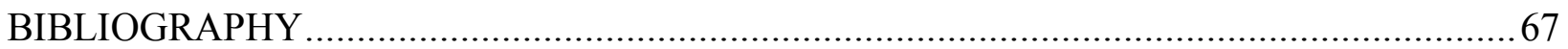




\section{LIST OF APPENDICES}

APPENDIX A-CADBORO BAY: INDEX TO AN INCOMPLETE HISTORY, (C MELINDA MOLLINEAUX, 1998

APPENDIX B-UNTITLED, FROM THE PHOTO SERIES KANAVAL, (C) LEAH GORDON,19932008

APPENDIX C-UNTITLED, FROM THE SERIES HOMETOWN QUEEN, C CAMILLE TURNER, 2010 .53

APPENDIX D-QUEEN OF THE BANDS: CARNIVAL AND “MONARCHY” IN THE 416, GALLERY INSTALLATION VIEW

APPENDIX E-QUEEN OF THE BANDS: CARNIVAL AND “MONARCHY” IN THE 416, GALLERY INSTALLATION VIEW OF ARCHIVAL IMAGES FROM TORONTO TELEGRAM

APPENDIX F-QUEEN OF THE BANDS: CARNIVAL AND “MONARCHY” IN THE 416,GALLERY INSTALLATION VIEW OF KEYWORD

APPENDIX G- FIGURE G-QUEEN OF THE BANDS: CARNIVAL AND “MONARCHY” IN THE

416, GALLERY INSTALLATION VIEW OF THE QUEEN PORTRAITS

APPENDIX H- QUEEN OF THE BANDS: CARNIVAL AND “MONARCHY” IN THE

416,GALLERY INSTALLATION VIEW OF THE KING AND QUEEN CARNIVAL

COMPETITION DAY .58

APPENDIX I-QUEEN OF THE BANDS: SUMMARY OF RESEARCH PARTICIPANTS 59

APPENDIX J-QUEEN OF THE BANDS: SUMMARY OF RESEARCH PARTICIPANTS 60 APPENDIX K-SUMMARY OF INTERVIEW QUESTIONS FOR MAIN RESEARCH PARTICIPANTS APPENDIX L-LIST OF ARCHIVAL REPORTAGE IMAGES....................................62 APPENDIX M-EMANCIPATION! CARNIVAL! ..............................................6 APPENDIX N-ARTIST STATEMENT......................................................65

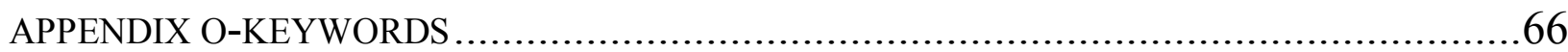




\section{A NOTE ON TERMINOLOGY}

Throughout this paper, I use various terms that reflected my research in emancipation and carnival history. By no means do I feel that this terminology is devoid of social-political implication, nor do I subscribe to the notion that African Canadian over such terms as Black Canadian hold a hierarchical position of political correctness. Each term has a place and can never completely define the variation in ethnic and racial representation that exists in Canada.

Scholars Wisdom J. Tettey \& Korbla P. Puplampu note that "the term African-Canadian is often used in everyday parlance and in the academic literature as an uncontested signifier of identity capturing all peoples of African origin in Canada." ${ }^{1}$ Tettey and Puplampu also note that the complexity of ownership and inclusion also create four distinct sites of understanding when using this term. They include "(1) The Immigration Authorities Approach; (2) The Black equals African/African equals Black Approach; (3) The Self-Exclusion Approach; and (4) The Authentic African Approach.”2

Both scholars mirror my understanding of the term African Canadian and highlight many valid points while also demonstrating the complexities of discussing the history of Black people in Canada. I would also extend the complexities of inclusion and ownership to terms such as West Indian, Anglo-Caribbean and Afro-Caribbean. These terms also contribute to connotations of segregation, and this becomes more exasperated because the Caribbean community is a multiracial, multi-ethnic group of people and countries.

During my research, I have been cognizant that the presence of Afro-Caribbean and African Canadians in Canadian carnival celebrations has been dominant, thus, disassociating the

\footnotetext{
${ }^{1}$ Wisdom J. Tettey and Korbla P. Puplampu, eds., The African Diaspora in Canada: Negotiating Identity and Belonging (Calgary: University of Calgary Press, 2005), 6, accessed May 27, 2018, https://dspace.ucalgary.ca/bitstream/handle/1880/48644/UofCPress_AfricanDiaspora_2005.pdf?sequence=5. 2 Ibid.,6.
} 
visual representation of Carnival in Canada with other members of the Caribbean community and creating a divide in the claim for cultural identity. Furthermore, it is important to be aware of the various origins of the term diaspora. Tettey and Puplampu provide a valuable starting point that fits the relationship between Caribbean emigrants and their representation in Canadian society. They state that diaspora "refers to a description of movement and location in the context of globalization. It also denotes a social condition and the processes that characterize it." ${ }^{3}$

The reference to globalization and its processes is one of the most integral elements needed when considering the notion of diaspora within the Carnival framework in Canada. In addition, scholar Charmaine Nelson notes that, particularly in the case of Black people in Canada, there is an experience of "double dislocation and multiple potential belongings which often have nothing to do with the geographical place/name on (their) birth certificate. ${ }^{\prime 4}$ Nelson further attributes the double dislocation to the "double diaspora effect," which is defined by a sense of being "doubly diasporized" by having ones ethnic or cultural origins be in Canada and in another nation that shares "an experience of heterogeneity" history.

With regards to Carnival terminology, the key term I use in this paper is Mas', which is the shortened form of Masquerade. In the wake of various scholars who have used the term, Mas' man Peter Minshall, one of the most recognized carnival costume designers in the world, notes that:

Mas' ....involves conception, design, craft, construction, making. The thing made is worn or carried by one or more persons. Something that may be twenty feet tall and forty' feet wide, or as minimal as grease smeared on the skin, two horns, a tail and a pitchfork. It

\footnotetext{
${ }^{3}$ Ibid., 4.

${ }^{4}$ Charmaine Nelson, Ebony Roots, Northern Soil: Perspectives on Blackness in Canada (Newcastle: Cambridge Scholars, 2011), 15 .

${ }^{5}$ Ibid.,17.

${ }^{6}$ Ibid.

${ }^{7}$ Ibid.
} 
also involves the act of the wearing, the person going into the street or onto the stage, and to the accompaniment of sound - a beaten rhythm, a speech, a soca road march, moving, dancing, miming, or otherwise portraying the thing, or idea, or mood, or character the costume or structure is meant to represent. ${ }^{8}$

Minshall's definition encompasses everything that is key to Mas', but it misses one crucial element: the importance of the spelling of the term Mas'. To illuminate this matter, I refer to scholar Adeola Patricia Dewis, who significantly contributes to the conversation, writing:

I favour the spelling option with the apostrophe as, in my view, it represents a sense of lineage (connection to another word), a sense of loss (apostrophe substituting something that is no longer there) and also shows potential for re--invention. In that regard mas' (with the apostrophe) can be aligned metaphorically as significant to the evolution of notions of Caribbean--ness. ${ }^{9}$

Dewis notion of a continuum, loss, and innovation is key to the understanding of Mas' because of its temporal nature, and these notions are also important in constructing my argument around Mas' and Queenliness.

Lastly, I would like to comment on the capitalization of "Black" in this paper. Many scholars in Canada and the United States have argued for and against the capitalizing of the term in regards to race. In my opinion, the capitalization of the term differentiates it from the description of the colour black and places it in accordance with the capitalization of other nationalities and races. In the Canadian media landscape, Chantal Braganza, a writer and producer at TV Ontario (TVO), aptly suggested in a 2016 article that after many conversations and changes by a few Canadian media outlets, writers at TVO.org chose to capitalize "descriptors" $" 10$ such as "Aboriginal, Indigenous and Black in recognition of these terms as identities and not adjectives." 11

\footnotetext{
${ }^{8}$ Peter Minshall, " “To Play Mas"," Caribbean Quarterly 45, no. 2-3 (1999):30.

${ }_{9}^{9}$ Adeola Patricia Dewis, "Carnival Performance Aesthetics: Trinidad Carnival and Art Making in the Diaspora," (PhD diss., Cardiff University, 2014), 1.

${ }^{10}$ Chantal Braganza, "Why We Decided to Capitalize Black, Aboriginal and Indigenous," TVO, October 07, 2016, accessed June 18, 2018, https://tvo.org/article/current-affairs/why-we-decided-to-capitalize-black-aboriginal-and-indigenous-.

11 Ibid.
} 
The article further notes that this action also helps "hundreds of thousands of Canadians" 12 contemplate the term in the context of history and community while also making strides in moving beyond the rules that the "Canadian Press Stylebook"13 sets out, which largely encourages the lowercasing of these descriptors. Overall, journalism scholar Lori L. Tharps sums up the argument around the capitalization of Black, stating that "Black should always be written with a capital B. We are indeed a people, a race, a tribe. It's only correct."14

\footnotetext{
12 Ibid.

13 Ibid.

${ }^{14}$ Lori L. Tharps, "The Case for Black With a Capital B," The New York Times, November 19, 2014, accessed June 18, 2018 , https://www.nytimes.com/2014/11/19/opinion/the-case-for-black-with-a-capital-b.html?smid=tw-share\&_r=1.
} 


\section{INTRODUCTION}

My master's research project started with an interest in documenting Queenliness through women of colour. The Collins English Dictionary defines Queenliness as deriving from the term queenly, meaning "in a manner appropriate to a queen." 15 During the early stages of my research process, I asked myself two questions. First, what does it mean to be a woman of colour performing as a queen in carnival celebrations that have roots in emancipation? Secondly, how does the representation of Queenliness change when you are a citizen of a country that pledges allegiance to the Queen of England and understands "Queenliness" within the realms of a historically dominant European figure?

The basis of my first question is rooted in my reflections as a young woman of colour born and raised in Toronto, Canada, experiencing the transplanted cultural traditions of Guyana because of my parentage. The second question derives from the notion that Canadian patriotism is largely centred on the traditions of British pomp and circumstance, especially when it comes to national communal celebrations.

To flesh out the answers to these questions, I photographically documented and interviewed four women. These women range in age and occupation, but the commonality among them is that they hold the leading masquerader role within the female category in four out of eleven Mas' bands, competing to gain the 2017 title Queen of the Bands. To reiterate the term Mas' is the shortened word for masquerade, used in the carnival community to define "the costume of an individual or the whole costumed theme of a band"16 participating in Toronto's

\footnotetext{
${ }^{15}$ Collins English Dictionary, Accessed October 29, 2017, https://www.Collinsdictionary.Com/Us/Dictionary/English/Queenly. ${ }^{16}$ Garth L. Green, Trinidad Carnival: The Cultural Politics of a Transnational Festival (Bloomington: University Press, 2007),230.
} 
Caribbean Carnival, formerly known as "Caribana."17 The Queens of the Band or "Carnival Queens"18 "are defined as the largest and fanciest female costume of any band."19 The women compete within the larger context of the King and Queen competition in costumes that weigh hundreds of pounds and tower several feet above them. Scholar Jacqueline Taucar notes that the "performer showcases the costume for the judges by "dancing the Mas" to music, requiring practice and an understanding of the costume's physics." ${ }^{20}$ She goes on to suggest that due to the magnitude of the costumes, "performers cannot make sharp, 360-degree turns. Rather, the Mas' is danced in large figure-eight patterns and circles in front of the judges and audiences... (with) floodlights, [emphasizing] the movement qualities of the Mas ... adding to the visual effect."21 The competition (or showcases as it's sometimes referred to) is described in a Toronto Caribbean Carnival press release as "the most spectacular show under the stars in North America." 22 The festivities also highlighted " the 50th anniversary of Carnival in Toronto." 23 The 2017 showcase included "performances by the legendary calypsonian David Rudder, ${ }^{24}$ soca artist Shurwayne Winchester,"25 and Ol' Time Carnival ${ }^{26}$, a folklore based theatrical

presentation. In total, there were thirty-three big Mas' costumes and eleven Mas' bands and, along with the grand prize, there was also the Innovation in Mas' Award ${ }^{27}$ presented by the

\footnotetext{
${ }^{17}$ Cecil Foster and Chris Schwarz, Caribana, The Greatest Celebration, (Toronto: Ballantine Books, 1995),18.

${ }^{18}$ Ibid.

${ }^{19}$ Garth L. Green, Trinidad Carnival: The Cultural Politics of a Transnational Festival (Bloomington: Indiana University Press, 2007),228.

${ }^{20}$ Jacqueline Taucar, "Making Mas: TruDynasty Carnival Takes Josephine Baker to the Caribbean Carnival," Canadian Theatre Review 152, no. 1 (Fall 2012): 21, accessed July 5, 2018, doi:10.1353/ctr.2012.0078.

${ }^{21}$ Ibid.,22.

22 Peeks Toronto Caribbean Carnival, Media, "Peeks Toronto Caribbean Carnival's King \& Queen Competition Most Spectacular Show Under the Stars Followed by North America's Largest Pan Alive," news release, June 06, 2017, Toronto Caribbean Carnival, accessed July 6, 2018, https://torontocarnival.ca/.

${ }^{23}$ Peeks Toronto Caribbean Carnival Festival, Marketing \& Public Relations, "King \& Queen Showcase to Celebrate 50 Years of Carnival Arts," news release, July 31, 2017, Toronto Caribbean Carnival, accessed July 5, 2018, https://torontocarnival.ca/.

${ }^{24}$ Ibid

${ }^{25}$ Ibid.

${ }^{26}$ Ibid.

27 Ibid.
} 
Ontario Science Centre for the past eight years. The Innovation in Mas' award, is given to the Mas' band that demonstrates "the best engineering, construction, design, and environmentally conscious use of material in a costume." 28

Overall, the purpose of my project is to clearly communicate, both orally and visually, the rich history of African Canadians in Toronto, the role of women in this history, and the commemoration of an Emancipation Day rooted event such as carnival. I chose to document Queens of the Bands in Toronto Caribbean Carnival to centralize a tangible element of this history. In addition to the main research participants, I interviewed the bandleaders who are the owners of each Mas' band, the CEO of the festival, a woman of Caribbean heritage, and, finally, the costume designers who contributed to the construction of each queen's costume.

When documenting my chosen subjects and spaces, I used elements of observational and participatory photography and portraiture to move within the spectacle that is carnival and beyond the performative representation of women to reveal each queen's everyday persona prior to their performance. My photographic documentation of the Mas' Camps, which is defined as the studio space were these queens' costumes are created, also held importance in my photographic process. The 2017 Toronto Caribbean Carnival King and Queen competition is the event that illuminates these women's performances and places the notion of Queenliness front and centre during the carnival season.

It is when the public experiences the first taste of the competitive nature of carnival before the parade, which further demonstrates the deep relationship carnival holds with the gaze of the spectators and the judges. Through the combination of photography and audio interviews

\footnotetext{
${ }^{28}$ Peeks Toronto Caribbean Carnival, Media, "New Name, Expanded Programming for Carnival's 50th Year," news release, June 1, 2017, Toronto Caribbean Carnival, accessed July 6, 2018, https://torontocarnival.ca/.
} 
in the Mas' camp, I flesh out the reasons why each woman chose to sacrifice her time and personal funds to take on the persona of the head female masquerader (Queen of the Bands) within the complex political framework of carnival in Toronto.

My research revealed that these women hold different levels of agency and participation, and it exists beyond the five minutes they have on stage during their King and Queen competition performances. Their connection to the mechanical nature of the costume lends to their ability to hold power in their movements, take up space, and demand attention. Each woman is clear about her responsibility and what her role entails. To clarify, Queenliness does not rely on physical beauty, age, or occupational position but has more to do with how actions and performance preserve the Caribbean culture within the context of carnival.

My additional objectives were the following. First, to evaluate how the historical framework of Emancipation Day in Ontario has shaped the current production of these celebrations in Toronto. Second, to contextualize the head female masquerader's position within the historical framework of emancipation and carnival. Third, to determine the role carnival celebrations play in defining a racialized woman's identity in Canadian society. Fourth, to investigate how employing documentary photography practices can shape the understanding of Emancipation Day and contextualize African Canadian history. Lastly, to investigate how employing documentary photography practices can shape the understanding of Emancipation Day and contextualize African Canadian history.

Also, a central aspect of my research on Queenliness is the relationship it has to British monarchal representation, which is prevalent in the national narrative of Canada. When I refer to British monarchal representation, I mean the commonwealth identity that those who live in both the Caribbean and Canada share. Regardless of the day-to-day consciousness of this 
representation, residents of both Canada and the Caribbean are affected in many ways, and I feel through my research on Queenliness that these aspects of commonwealth identity can be unpacked. I discuss the historical significance of this relationship in the sub-section 1.2.1-Will the "Citizens" Please Rise: Commonwealth Identity in Canada.

The historical framework I have previously discussed also led me towards the archive. The archive was important in my research for various reasons, but, perhaps most importantly, because it was the 50th anniversary of carnival in Toronto. Due to the depth of this history, I wanted to gain a deeper understanding of the photographic and textual documentation that predated my own knowledge and approach.

I conducted archival research in Clara Thomas Archive and Special Collections held at York University in Toronto, Canada. In the archive, I explored early Emancipation Day parade images from Toronto ranging from 1964 to1965. These photos reinforce the textual documentation that defines the Emancipation Day celebrations as formal, patriotic, and militaryfocused, which strongly influences the evolution of Black communal celebrations in Toronto. I also explored the carnival archive of Miss Caribana, a pageant that ran from the late 1960s to the late 1980s. The Miss Caribana photographs I sourced from the archive were taken by various newspaper photographers during the 1970s for the Toronto Telegram.

The photo negatives included a variety of images from the event, some representing the more traditional aspects of pageantry, such as the crowning ceremony and others depicting the essence of carnival costuming, which were included in the pageant to reflect the carnival season. During the early years of the pageant, the participants shared a space with Caribana's first King and Queen competition on Toronto island, ${ }^{29}$ but in later years, the pageant took place at the

\footnotetext{
${ }^{29}$ Nora McCabe, "Miss Caribana 71' Is Crowned, Costume Goes up in Flames but Wins First Prize," Toronto Daily Star (Toronto, Ontario, Canada), July 31, 1971, What's Happening sec.
} 
"Royal York Hotel" 30 during the Caribana ball and would run for "30 minutes." 31 The women in the pageant were judged on their evening gowns and ability to be "poised, intelligent and beautiful." ${ }^{32}$ as well as their pageant costume.

In addition, the archival images of the Caribana King and Queen competition that are included in my exhibition are from the first competition in 1971 and depict both men and women vying for their respective titles. There were six queens and seven kings ${ }^{33}$ who competed in front of five judges for a prize worth "800 dollars." 34 In the early days, both the kings and queens were judged on "splendour, theme, meaningfulness, workmanship, carnival spirit, originality and uniqueness." 35 Overall, these images speak to the evolution of Queenliness in the Canadian carnival archive. I will further elaborate on my archival research and exploration in the methodology section, 2.1.4 The Role of The Archive.

\subsection{SOCIOCULTURAL AND HISTORICAL CONTEXT}

\subsection{1-Emancipation Day in Toronto: A Display of Communal Consciousness}

Before I dive into the celebrations of Emancipation Day, it is important to discuss the origins of African Canadians in Canada. Dr. Afua Cooper, The James Robinson Johnston (JRJ)

${ }^{36}$ chair in Black Canadian studies, ${ }^{37}$ suggests in the foreword of the book Emancipation Day: Celebrating Freedom in Canada by current Ontario Black History Society president Natasha L. Henry $^{38}$ that during the time Canada was under the rule of the British Empire, Canada gained

\footnotetext{
${ }^{30}$ Claudio Lewis, “Introducing: Miss Caribana '77," Contrast Newspaper, July $28^{\text {th }}, 1977,15$.

${ }^{31}$ Ibid.

${ }^{32}$ Ibid.

${ }^{33}$ Nora McCabe, "Miss Caribana 71' Is Crowned, Costume Goes up in Flames but Wins First Prize," Toronto Daily

Star (Toronto, Ontario, Canada), July 31, 1971, What's Happening sec.

${ }^{34}$ Ibid.

35 Ibid.

${ }^{36} \mathrm{JRJ}$ is the acronym for The James Robinson Johnston Chair in Black Canadian studies at Dalhousie University.

37 "Afua Cooper," Dalhousie News, accessed May 24, 2018, https://www.dal.ca/faculty/arts/sociology-socialanthropology/faculty-staff/our-faculty/afua-cooper.html.

38 "Message - OBHS President," Ontario Black History - Home, 9, accessed June 15, 2018, http://www.Blackhistorysociety.ca/message---obhs-president.html.
} 
immensely from slave labour, noting "though (Canada) was not a slave society, it was a society with slaves...beginning in $1628 . "{ }^{\prime 39}$ In addition, in Chasing Empire Across the Sea, Kenneth J. Banks notes that out of "4000 slaves in New France (now Quebec) 1,400 were of West African descent, and the majority of these were introduced after the British Conquest of 1760." ${ }^{\circ 0}$

Furthermore, Maureen G. Elgersman-Lee notes in Unyielding Spirits: Black Women and Slavery in Early Canada and Jamaica that British colonists upheld "the Quebec Act of 1774"41, which aided in the retention of slaves by French colonists. She further states that by $1792,{ }^{42}$ the nation's law transitioned to British law. Elgersman-Lee affirms that this transition complicated the stance and position of those who participated in slavery. The solution was to "de facto"43 slavery and proceed with the law to uphold slave practices on the belief that people of colour, particularly Black people, were "fit for enslavement." ${ }^{\text {" }}$ The numbers mentioned and the actions of both the French and British empires solidify the presence of Black enslaved persons in Canada and demonstrate the complex negotiations of colonial conquest and ownership.

The institution of slavery and its history in Canada have been uncovered but have not been nationally integrated into Canada's curriculum or mainstream broadcasted narratives. Some may ask, what about the efforts of Historica Canada,${ }^{45}$ who produces nation-wide broadcasts of Canadian history through "dramatized vignettes," 46 fondly known as Heritage Minute? ${ }^{47}$ The keyword to note is "minute," which adds to both the understanding and collective amnesia of the

\footnotetext{
${ }^{39}$ Afua Cooper, Foreword to Natasha Henry, Emancipation Day: Celebrating Freedom in Canada (Toronto: Natural Heritage Books, 2010), 10.

${ }^{40}$ Kenneth J. Banks, Chasing the Empire Across the Sea: Communications and the State in the French Atlantic, 1713-1763 (Montreal and Kingston: McGill-Queen's University Press, 2003), 140.

${ }^{41}$ Maureen Elgersman Lee, Unyielding Spirits: Black Women and Slavery in Early Canada and Jamaica (New York: Garland Pub., 1999), 26.

42 Ibid.

${ }^{43}$ Ibid.

${ }^{44}$ Ibid.

45 “About" Historica Canada, accessed May 23, 2018, https://www.historicacanada.ca/about.

${ }^{46}$ Ibid.

${ }^{47}$ Ibid.
} 
public. To share and inform are important, and the visuals produced by Historica Canada contribute to this in a very successful way, but if Canadian audiences, unfamiliar with the history of African Canadians, become solely reliant on these dramatizations as a gateway to further their knowledge, then collective understanding and interactions with African Canadian narratives, become limited to what the visuals in these vignettes prioritize.

These visuals may or may not align with Black Canadian communities and how they want their stories to be projected on the nation. Further, I want to make clear that my argument is not an attack on the short film genre or the validity of vignettes, but more specifically, the way that these attempts to visualize African Canadian history can alternatively be used to validate an argument that denounces the need for Canada to provide further educational tools and depictions of African Canadian narratives on a broader scale. Due to the authoritative voice of organizations like Historica Canada and their relationship with the federal department of Canadian Heritage.

To increase the totality of understanding amongst the public, scholars have called for an increase in African Canadian history and curriculum at the elementary, secondary and postsecondary level as well as a more active approach from broadcasters such as the Canadian Broadcasting Corporation ( $\mathrm{CBC}$ ) to produce series that add to the understanding of African Canadian narratives across the nation. Historian Ken Donovan notes that "unlike their Caucasian contemporaries, most African Canadians know about slavery." ${ }^{~ 48}$ However, slavery or the act of enslavement continuously takes a back seat in the minds of many Canadians. He suggests that the reason behind this is due to "the liberal principle of the development of individual or human rights that emerged throughout the $19^{\text {th }}$ and $20^{\text {th }}$ century." ${ }^{.49}$

\footnotetext{
${ }^{48}$ Ken Donovan, "Slavery and Freedom in Atlantic Canada's African Diaspora: Introduction. "Acadiensis 43, no. 1 (2014),110. http://www.jstor.org/stable/24329578

${ }^{49} \mathrm{Ibid}$.
} 
He notes that the introduction of "the Charter of Rights and Freedoms in the 1982 Canadian constitution," 50 directly affected the universal knowledge of Canada's relationship to enslavement, more specifically Black enslavement. In addition, Canada has a well-documented fascination with multicultural nationhood. This fascination was solidified with "the passage of the 1988 Multicultural Act," ${ }^{51}$ which established Canada as "the first official multicultural country in the world." ${ }^{52}$ This designation contributed to Canada's persona as a safe haven for those in need of humanitarian compassion, has dominated the national narrative, and has subsequently pushed the narrative of the enslaved to the side, which in turn has affected the descendants of those who have become affected by this horrible history.

It is also important to mention that the legitimacy of Black Canadian's claim to national belonging should not be solely reliant on the historical records of those enslaved. Nelson states, "to buy into the idea of historical presence [as] (a means of belonging) is to accept and to contribute to a limited colonial logic which privileges certain forms of geographical emplacement over mobilities, trajectories and other types of engagement with place."53 Nelson's sentiments are important to highlight in the context of my research because they reiterate the complexities of the hierarchal claim to identity and belonging. Nelson's perspective provides the room for newer generations of Black Caribbean Canadians and other people of colour who hold Caribbean and African ancestry to stand firm in their identity as Canadians without "dismissal or minimization." $" 54$

\footnotetext{
${ }^{50}$ Ibid.

${ }^{51}$ Wisdom J. Tettey and Korbla P. Puplampu, eds., The African Diaspora in Canada: Negotiating Identity and Belonging (Calgary: University of Calgary Press, 2005), 6, accessed May 27, 2018, https://dspace.ucalgary.ca/bitstream/handle/1880/48644/UofCPress_AfricanDiaspora_2005.pdf?sequence=5. ${ }^{52}$ Ibid.

${ }^{53}$ Charmaine Nelson, Ebony Roots, Northern Soil: Perspectives on Blackness in Canada (Newcastle: Cambridge Scholars, 2011), 2.

${ }^{54}$ Ibid., 2.
} 
A critical moment in the trajectory of Emancipation Day in Canada was the passing of legislation in 1793 known as "The Act to Prevent the Further Introduction of Slaves, and to Limit the Term of Contact for Servitude." ${ }^{55}$ Initiated by Lieutenant Governor Lord John Graves Simcoe, and passed in what was known as Upper Canada. The Act was slotted as the first legislation to put an end to slavery but was met with resistance by Governor Simcoe's cabinet, who were "slave owners" 56 at that time. Simcoe was extremely vocal in his disdain for the institution of slavery and was well known in Britain for his "abolitionist campaign." 57

His cabinet decided to introduce the limiting of further enslavement legislation as a compromise to his demands. Simcoe's legislation came into effect around the same time the United States passed its "first federal fugitive slave law"58, which affected the relationship between Canada and its neighbour to the south when it came to enslavement. This marked the start of a "legal and moral dichotomy in terms of the status of Blacks inside and outside of Canada." $" 59$

As Elgersman-Lee notes, the story of an enslaved young Black woman named Chloe Cooley, who was forcibly removed and "bound for transport to the US," 60 also was a significant component of the legislation passing. After this legislation was passed, a large amount of "fugitive (slaves) immigrated"61 to Canada because of the new prospects of freedom, but it took an additional forty years for the British Empire to legislate the end of slavery.

\footnotetext{
${ }^{55}$ Natasha Henry, Emancipation Day: Celebrating Freedom in Canada, (Toronto: Natural Heritage Books, 2010$), 41$.

${ }^{56}$ Maureen Elgersman Lee, Unyielding Spirits: Black Women and Slavery in Early Canada and Jamaica (New York: Garland Pub., 1999), 26.

${ }^{57}$ Ibid.,26.

${ }^{58}$ Ibid., 27

${ }^{59}$ Ibid., 27

${ }^{60}$ Ibid., 27

${ }^{61}$ Ibid.,42
} 
It is evident that the Canadian economy had many links to slave practices within the country and outside of its borders, as early as "the days of New France." ${ }^{\prime 2}$ The relationship and history between the Caribbean and Canada have been well documented and should always be studied with a "hemispheric historical awareness." ${ }^{63}$ In a nineteenth-century census, ${ }^{64}$ Cooper notes that enslaved men and women identified themselves as "West Indian," ${ }^{65}$ which is an early term used to denote people of Caribbean origin. She goes on to suggest that "Caribbean slaves for at least two centuries survived on salted cod and wheat flour from what is now Canada,"66 and, in return, the Caribbean supplied "rum, sugar, molasses, and slaves." ${ }^{67}$ Canada also contributed to the building of "slave ships."68 This Caribbean Canadian or "West Indian" exchange, as it was labelled at the time, was one of the earliest connections that Canada had with slavery in the Caribbean.

In the British Caribbean, ${ }^{69}$ as it was previously referred to, the passing of the 1833 Slavery Abolition Act triggered the emergence of a carnival-style Emancipation Day celebration, which included various "African influenced cultural rituals" 70 and presentations, such as the "Jonkunnu and Canboulay."71 The Emancipation era carnival Canboulay stems from the French term "Cannes Brule," 72 which translates to "burning canes" $" 73$ and is a "direct reference to the

\footnotetext{
${ }^{62}$ Afua Cooper, "Constructing Black Women's Historical Knowledge," Atlantis: Critical Studies in Gender, Culture \& Social Justice 25, no. 1 (October 1, 2000): 42, accessed June 15, 2018, http://journals.msvu.ca/index.php/atlantis/article/view/1544.

${ }^{63}$ Ibid, 42.

${ }^{64}$ Ibid.

${ }^{65}$ Ibid.

${ }^{66}$ Ibid.

${ }^{67}$ Ibid.

${ }^{68}$ Natasha Henry, 41.

${ }^{69}$ Ibid., 43.

${ }^{70}$ Ibid.

${ }^{71}$ Ibid.

72 J. D. Elder, "Cannes Brûlées," TDR 42, no. 3 (Autumn 1998): 38, 2006, accessed July 9, 2018, doi:10.1162/105420498760308436.

${ }^{73}$ Karolee Stevens, "Carnival: Fighting Oppression with Celebration," Totem: The University of Western Ontario Journal of Anthropology, 14th ser., 2, no. 1 (Spring 1995): 65, accessed July 4, 2018, https://ir.lib.uwo.ca/totem/vol2/iss1/14.
} 
end of enforced sugar cane production." 74 in the Caribbean. Canboulay is also noted by J.D.elder as "a ceremony ...that Africans of Trinidad devised to celebrate their "freedom from slavery" in 1838."75

While Jonkunnu is a carnival celebration that occurs during "Christmas and New year's"76 in certain Caribbean countries that celebrate carnival. Jonkunnu can also be spelled as “Jankunu, John Canoe, Jonkonnu, Junkanoo, John Kuner"77 and has been described as "a beautiful symbol of surviving African "spirit" in [the] English-speaking Americas."78 These celebrations were reminiscent of current carnival celebrations because they included "dancing, parading and theatrical shows." 79

Another connection that emancipation and carnival share is in the earliest naming of Emancipation Day celebrations in Ontario. The use of the name "August First," date slavery became abolished in Canada was also previously known as "West India Day." 81 This was because both Canada and various countries in the Caribbean were colonies under British rule, and, when slavery was abolished, there were over "one million Africans" 82 freed from Caribbean (West Indian) countries. This was one of the largest numbers of people freed from bondage, so there was a need for solidarity through celebrations in all the colonies.

Ontario's relationship to Emancipation Day is significant, with a history of African Canadian and communal gatherings established for over 183 years, with the first official

\footnotetext{
${ }^{74}$ Ibid

75 J. D. Elder, "Cannes Brûlées," TDR 42, no. 3 (Autumn 1998): 38, 2006, accessed July 9, 2018, doi:10.1162/105420498760308436.

${ }^{76}$ Kenneth M. Bilby, "Surviving Secularization: Masking the Spirit in the Jankunu (John Canoe) Festivals of the

Caribbean," New West Indian Guide / Nieuwe West-Indische Gids 84, no. 3-4 (2010): 180, accessed July 5, 2018.

${ }^{77}$ Ibid

${ }^{78}$ Ibid.

${ }^{79}$ Natasha Henry, 43.

${ }^{80}$ Natasha Henry, Emancipation Day: Celebrating Freedom in Canada (Toronto: Natural Heritage Books,2010),10.

${ }^{81} \mathrm{Ibid}, 35$. The term West India references the term West Indian, with which people of Caribbean origin have been identified throughout history.

82 Ibid.
} 
gathering starting in $1834 .^{83}$ These gatherings commemorated the abolishment of slavery in Ontario and the emancipatory relationship Canada held with other countries, which were under the colonial rule of the British Empire. Throughout the years there were several themes that emerged in the commemoration of Emancipation Day in Ontario.

Henry notes that these themes included a concentration on the "liberation [of] enslaved Africans in British colonies, ${ }^{\circledR 84}$ the ongoing fight for freedom for those who remained in bondage, ${ }^{, 85}$ the marking of the status change for people of African descent, moving from "chattel property to persons entitled to rights and privileges," $" 86$ and finally gratitude towards "Canada's assistance to Black refugees of slavery or Black Loyalists." ${ }^{" 87}$ There was also tension felt by many participants of these early Emancipation Day celebrations because some people among the events felt that there was not much to celebrate. There was still widespread oppression due to the "daily realities of racial discrimination, lack of job opportunities... and the denial of housing and education, ${ }^{, 88}$ among other tribulations. These tensions, to a lesser degree, continue to this day, adding to the complexity of the celebration.

In Toronto, historically known as the town of "York,"89 there were large processions for Emancipation Day, with the first parade being held as early as $1838 .{ }^{90}$ Church services were dominant in these events, with the earliest church service being held at the "African Methodist Church or (AME)" ${ }^{" 91}$ on "Richmond and York Street."

${ }^{83}$ Ibid., 17.

${ }^{84}$ Natasha Henry.,26.

85 Ibid.

${ }^{86}$ Ibid.

${ }^{87}$ Ibid.

${ }^{88}$ Ibid.,28.

${ }^{89}$ Ibid., 128

${ }^{90}$ Ibid., 129 .

${ }^{91}$ Ibid.

${ }^{92}$ Ibid. 
stretched from "College Avenue to Union Station"93 and eventually north on "Church street to St. James Cathedral"94 for speeches and prayer. Emancipation Day celebrations in Toronto took on strong importance because the African Canadian population in the city at the time was growing at a rapid rate.

There was a large influx of refugees from America, most arriving by the "1860's." 95 This influx of people consisted of "two thousand plus"96 individuals and families. Various societies were involved with the Emancipation Day initiatives, but most notably the "Toronto Abolition Society," which sponsored the event from the "1830s" to the late "1840s." groups also were recognized as holding these events, one being the "Black Loyalists"98 who fought under the British and another group defined as "new fugitives" 99 who escaped enslavement in the United States.

It is also important to note that Black women organizations held a role in Emancipation Day celebrations. Their involvement started in the background, which was customary at the time. It was the Victorian era, and women did not have the "right to vote or own property,"100 and they could only hold the occupation of a "teacher."101 As women's rights grew, so did their visibility. From the holding of "tea parties," 102 to addressing the crowd during the celebrations, Black women's voices were starting to be heard. It is said that in "1854,"103 the voice of "Mary Ann Shadd [Cary], publisher of the Provincial Freeman,"104 an anti-slavery newspaper, was one of

\footnotetext{
${ }^{93}$ Natasha Henry., 133.

94 Ibid.

${ }^{95}$ Ibid.,128.

${ }^{96}$ Ibid., 124.

${ }^{97}$ Ibid., 129

98 Ibid.,128.

99 Ibid.

${ }^{100}$ Ibid.,200.

${ }^{101}$ Ibid.

102 Ibid., 130.

${ }^{103}$ Ibid.,200.

${ }^{104}$ Ibid.,130.
} 
the first speakers. It is also largely noted that Mary McLeod Bethune, a "civil rights activist and advisor to President F.D. Roosevelt," 105 was declared the first woman invited to speak at an Emancipation Day event in Ontario. "Anglo-Canadian identity"106 permeated throughout these early celebrations, as there was a strong lean towards conservative values and "British cultural customs," 107 such as calling allegiance to Her Majesty the Queen of England and drinking British tea. The military influence was also strongly felt in these celebrations, which demonstrated the ongoing relationship the African Canadian community had with British military service in exchange for "freedom in British colonies." 108

Many Black men served in various wars, including the "War of 1812 and the rebellions of 1837."109 Black members of the military were said to represent "loyalty and patriotism."110 The presence of military service members continued into the 1953 Emancipation Day celebration, held by the "Toronto Emancipation Committee"(TEC), ${ }^{111}$ an organization run in large part by "Donald Moore, a community activist and director of the Negro Citizenship Association." 112 These celebrations included lodges, churches, military groups, and community organizations. More prominent in these celebrations was the presence of government officials from all three levels of government and the discussion of "Canada's immigrant policy."113 Starting in 1996, the "Ontario Black History Society"114 and the organization's former president Rosemary Sadlier brought the celebration to the forefront, establishing an annual event in Toronto's Queens Park and inside the Ontario Legislative Building that still is held to this day.

\footnotetext{
105 Ibid.,200.

${ }^{106}$ Ibid.

${ }^{107}$ Ibid.

${ }^{108}$ Ibid.,32.

109 Ibid.

${ }^{110}$ Ibid.

111 Ibid.,136.

112 Ibid.

113 Ibid.,141.

${ }^{114}$ Ibid.,143.
} 
The event was widely advertised during and after the 2008 passing of Bill 111, ${ }^{115}$ an Act to Proclaim Emancipation Day, "the very first co-sponsored bill introduced in the history of Ontario." 116 The bill was initiated by Sadlier and supported by Progressive Conservative MPP Ted Arnott and Liberal MPP Maria Van Bommel. Its passing proclaimed August $1^{\text {st }}$ as Emancipation Day in the province of Ontario. Before Bill 111, there was no provincial legislation recognizing Emancipation Day, and in August 2018, the bill celebrated its tenth anniversary.

In addition, a private citizen in conjunction with members of the Royal Commonwealth Society of Canada held an Emancipation Day Campaign $^{117}$ from July 2017 to February 2018, soliciting signatures through an online petition to recognize Emancipation Day across Canada. Their initial online petition gained 1,156 digital signatures, ${ }^{118}$ but the organization wanted to obtain official national recognition, so on October 18, 2017, a member of the organization launched a official federal governmental E-petition called E-petition $1289 .{ }^{119}$

The E-petition was successfully presented in the Canadian House of Commons in Ottawa on February $28^{\text {th } 120}$ and sponsored by Liberal MP Nathaniel Erskine-Smith and further tabled for government response on April 16, 2018, ${ }^{121}$ but further movement on the e-petition was absent at the time of writing this paper. When taking a closer look at the evolution of Emancipation Day celebrations in Ontario, one can determine that the Black communal event has

\footnotetext{
${ }^{115}$ MPP Ted Arnott, Official Report Journal of Debate, First Session, 39th Parliament, $2^{\text {nd }}$ Reading of Bill 111(Toronto, Publish by the Legislative Assembly of Ontario, Thursday, December 4, 2008).

116 Ibid.

117 "Declare August 1st as Emancipation Day In Canada," The Royal Commonwealth Society of Canada-Emancipation Day, Accessed June 16, 2018, http://www.rcs.ca/emancipation_day.html.

118 "Sign the Petition," Change.org, accessed June 16, 2018, https://www.change.org/p/justin-trudeau-make-august-1 stemancipation-day-in-canada.

119 "E-1289 (National Day)," Paper Petitions - Guide For The Public, Accessed June 16, 2018, https://petitions.ourcommons.ca/en/Petition/Details?Petition=e-1289.

${ }^{120}$ Ibid.

121 Ibid.
} 
changed from a gathering heavily influenced by early British Victorian era traditions to the current and most visible and widely known manifestation of Emancipation Day-related events in the city, the Toronto Caribbean Carnival.

\subsection{2-Will the "Citizens" Please Rise: Commonwealth Identity in Canada}

In 2004, the Commonwealth contained 54 members, ${ }^{122} 33$ republics, ${ }^{123}$ and 16 constitutional monarchies. ${ }^{124}$ In Canada, the notion of Commonwealth identity is a complex mix of camaraderie, dependence, disdain, and obsession. David Merchant and Paul Rich suggest that "all members (of the Commonwealth, have) accept[ed] HM Queen Elizabeth II as the symbol of their association ... and some, such as Canada, also accept her as their head of state."125 The notion of patriotism, inclusion and monarchial representation have been important aspects to consider in my investigation of Queenliness when performed by women of colour.

What has intrigued me the most within arguments around Canada's inclusion in the Commonwealth are the British "ceremonial trappings of identity." 126 These trappings are most reflected in the traditional ceremonies of both present and past celebrations of Emancipation Day in Toronto. Further, Merchant and Rich note that the Commonwealth was once a racist deal among "old dominions," 127 and now is an economical and "moral"128 entity. The Commonwealth also provides "a way to be global but different. This is one club that the Americans cannot join and dominate, something which gives Canada a uniqueness." 129

\footnotetext{
${ }^{122}$ MPP Ted Arnott, Official Report Journal of Debate, First Session, 39th Parliament, $2^{\text {nd }}$ Reading of Bill 111(Toronto, published by the Legislative Assembly of Ontario, Thursday, December 4, 2008).

123 Ibid.

${ }^{124}$ David Merchant and Paul Rich, "Canada and the Commonwealth," American Behavioral Scientist 47, no. 10 (2004): 1319, doi: $10.1177 / 0002764204264257$.

125 Ibid.

${ }^{126}$ Ibid., 1323 .

127 Ibid., 1320.

128 Ibid.

${ }^{129}$ Ibid.,1322.
} 
In Canada, the enchantment with the monarchy sways back and forth depending on the presence of the royal family in the country. For example, when Prince William and Princess Catherine, Duke and Duchess of Cambridge, made a trip to Canada in 2011, Ipsos Reid, one of Canada's leading market intelligence and public opinion researchers, published a press release presenting results from a nationwide poll conducted after the royal visit. The survey asked Canadians about the royals and the monarchy in Canada; needless to say, the country was smitten with the royal couple with " 8 in 10 Canadians," $" 130$ suggesting that the Duke and Duchess of Cambridge's visit to Canada cemented the future of the monarchy.

In addition, when Canadians were polled on identity formation and monarchy, six in ten Canadians ${ }^{131}$ suggested that monarchy affects "Canadian identity formation," 132 and when looking at opinions by provinces, Quebecers hold a $59 \%{ }^{133}$ average towards cutting ties to Queen Elizabeth and the monarchy when her reign ends. This is a majority compared to the rest of the Canadian population with only $44 \% .{ }^{134}$ The discrepancy between Quebecers $(59 \%)^{135}$ who want to cut ties to the monarchy versus Ontarians (36\%) reveals a difference in margin of $23 \%$, which reflects the notion of British allegiance to anglophone nations because of the dominance of the historical relationship Quebec holds with the French colonialists versus the British.

From the data, one can determine that national identity and allegiance to sovereignty among Canadians have been dependent on whether one holds an Anglophone or Francophone connection through cultural identification or residency. Scholar Jatinder Mann, discussing the

\footnotetext{
${ }^{130}$ Ipsos Reid, Culture, "Canadians See the Future of the Monarchy in Canada...," news release, July 13, 2011, Ipsos News \& Polls, accessed May 26, 2018, https://www.ipsos.com/en-ca/canadians-see-future-monarchy-canada-falling-head-over-heelswills-and-kate.

${ }^{131}$ Ibid.

${ }^{132}$ Ibid.

${ }^{133}$ Ibid.

${ }^{134}$ Ibid.

135 Ibid.
} 
evolution of the Commonwealth, notes that "the presence of the French-Canadians, a competing founding group," 136 who occupied Canada before their British counterparts, helped in cementing the "British self-identification of English-speaking Canada."137

The debate among Anglophones and Francophones about the Commonwealth exclusionary tactics led to the forming of the 1947 Canadian Citizenship Act, ${ }^{138}$ which was less based on nationalism than on the compromise between the two recognized founding nations to hold the title of a Canadian citizen. The Bloc Populaire Canadien ${ }^{139}$ insisted on a compromise to protect their rights to an "assertive" 140 claim of Canada. Overall, the debate about the Commonwealth and Canadian national identity demonstrates the complexities of discussing notions of queenliness and monarchy within the framework of carnival and Emancipation Day celebrations.

\subsection{3-A Centennial Gift Turns Gold: Toronto Caribbean Carnival at Fifty}

Peeks Toronto Caribbean Carnival, as it has recently been dubbed due to new sponsorship, is cited as one of the "largest street festival(s) in North America,"141 and overtime is the result of community organizing and the dedication of Toronto's Anglo-Caribbean community to the preservation of Caribbean culture. Before the official founding of the carnival, a group of Black women from the 1950s had a role in the evolution of the festival. Lyndon A. Phillip suggests that "From 1951 to 1976, a group of Canadian-born Black women, the "Canadian

\footnotetext{
136 Jatinder Mann, "The Evolution of Commonwealth Citizenship, 1945-1948 in Canada, Britain and Australia," Commonwealth \& Comparative Politics 50, no. 3 (July 2012): 294, doi:10.1080/14662043.2012.692923.

${ }^{137}$ Ibid.

138 Ibid.,295.

139 Ibid.,296

140 Ibid.

${ }^{141}$ Afua Cooper, foreword to Natasha Henry, Emancipation Day: Celebrating Freedom in Canada (Toronto: Natural Heritage Books, 2010), 12.
} 
Negro Women's Association (CANEWA), initiated the first Black history celebrations in Ontario,"142 which led to "annual events they called Calypso Carnivals.

The Calypso Carnival had various roles of significance for the community of the $1950 \mathrm{~s}$, 1960s, and 1970s, such as "community scholarships"143 and the establishment of a "positive public image." 144 The women involved in CANEWA were noted to lack political consciousness due to their publicized "middle-class values," 145 which did not align with the social-economic struggle many of the new Caribbean emigrants to Canada faced. In addition, most of the women in the organization were born in Canada, and so was much of their ancestral lineage, so their "Canadian experience (was not associated to those) from the Caribbean." ${ }^{146}$ Phillip further refers to the connection between carnival and emancipation, stating that "the Emancipation Day Parade of years past was the most visible Black event in the city. This role was eventually relinquished to Caribana."147 The relationship between Afro-Caribbean Canadians and Black Canadians with ancestral links to those enslaved in Canada and America is deep and, as noted, not without its share of complications.

Scholar, Rinaldo Walcott has affirmed that "Blackness" in contemporary Toronto occupies a very specific place of visuality that is characterized by its diasporic connectedness in terms of a number of contradictory attachments."148 Walcott further suggests that "the single most outstanding performance element of "Blackness" in Canada (is) Caribana,"149 now Toronto

\footnotetext{
${ }^{142}$ Lyndon Phillip, "Reading Caribana 1997: Black Youth, Puff Daddy, Style, and Diaspora Transformations," in Trinidad Carnival: The Cultural Politics of a Transnational Festival, ed. Philip W. Scher and Garth L. Green (Bloomington: Indiana University Press, 2007), 105.

143 Ibid.

${ }^{144}$ Ibid.

145 Ibid

${ }^{146}$ Ibid

147 Ibid., 102.

148 Rinaldo Walcott, "Emerging Diaspora Consciousness among African-Canadians in Toronto," in Encyclopedia of Diasporas: Immigrant and Refugee Cultures around the World, by Melvin Ember and Carol R. Ember (New York: Springer, 2005$), 439$.

${ }^{149}$ Ibid.
} 
Caribbean Carnival. He legitimizes the claim by noting that the visual representation of attendees or the large number of "diasporan Africans" 150 attribute to the festival's relationship with Blackness.

The implication of race was something that weighed on my documentation and notions of Queenliness in the festival's King and Queen competition because of the diversity of the women who perform as queens in the festival and also because of the large diversity in the Caribbean. Walcott echoes my sentiments and suggests that the festival also stands as "an excellent example of Toronto as a creole city"151 because of its connections to notions of multiculturalism and its associated policies in Canada.

The carnival celebrations in Ontario started in $1967^{152}$ and were created to commemorate the Centennial ${ }^{153}$ birthday of Canada's Confederation. At the time, Caribana was viewed as a symbol of "power and achievement"154 as well as a "promise for potential"155 in the larger community. The festival was put forward as a gift from the Caribbean community and came into existence because of the "new wave." 156 Scholar Afua Cooper states that many from the Caribbean "arrived after the Second World War (because of the) labour demands of the post-war period." ${ }^{\prime 157}$ Cooper also points out that "Canada opened its doors to "selective" immigrants from the Caribbean." 158 The selectiveness includes the women of the "domestic scheme," 159 which

\footnotetext{
150 Ibid.

${ }^{151}$ Ibid

${ }^{152}$ Natasha Henry, Emancipation Day: Celebrating Freedom in Canada (Toronto: Natural Heritage Books, 2010$), 128$.

${ }^{153}$ Ibid.

${ }^{154}$ Cecil Foster and Chris Schwarz, Caribana, The Greatest Celebration (Toronto: Ballantine Books, 1995), 50.

${ }^{155}$ Natasha Henry, Emancipation Day: Celebrating Freedom in Canada, (Toronto: Natural Heritage Books, 2010$), 128$.

156 Ibid.,20.

${ }_{157}$ Afua Cooper, "Constructing Black Women's Historical Knowledge," Atlantis: Critical Studies in Gender, Culture \& Social Justice 25, no. 1 (2000): 42, accessed June 15, 2018, http://journals.msvu.ca/index.php/atlantis/article/view/1544.

${ }^{158}$ Ibid.

${ }^{159}$ Natasha Henry, 20.
} 
called for West Indian women to work as domestics in Canada from both the "French and British Caribbean" as well as the Black nurses of "exceptional merit"160 who were also represented.

The participants in carnival known as the masqueraders vary in age, race, and occupation, but Joan Pierre, former executive director of Caribana in the 1990s (when the festival was run by its predecessor, the "Caribbean Cultural Committee (CCC),"161 states that when you play Mas" you are no longer 'the doctor, lawyer, engineer or anything else because you're part of the band." "162 She continued to note that in the midst of carnival, there is no tension amongst masqueraders on the day of carnival because you can "drop all your inhibitions."163 Her sentiments are reflective of the current carnival landscape and continue to be one of the main links of carnival to the notion of freedom in Emancipation Day commemoration practices. On the road or during the performance of masquerade, you have permission to express yourself and take on the persona you have dressed up as on carnival day.

The current celebration is run by the Festival Management Committee (FMC) ${ }^{164}$, which is led by current Chief Executive Officer Denise Herrera Jackson (CEO) and a group of board members, mainly from the Caribbean Canadian community. The FMC took over from the CCC in 2006 and is a committee overseen by the City of Toronto. In 2010, two City of Toronto councillors noted in a member motion that "the festival is an anchor in Toronto's summer calendar." ${ }^{165}$ Councillors Michael Thompson and Joe Mihevc also stated that in 2009, an Ipsos Reid Economic Impact Study of Toronto Caribbean Carnival found the "economic impact of the

\footnotetext{
${ }^{160}$ Cooper, "Constructing Black Women's Historical Knowledge," 42.

${ }_{161}$ Cecil Foster and Chris Schwarz, Caribana, The Greatest Celebration (Toronto: Ballantine Books, 1995), 44.

162 Ibid.

163 Ibid.

164 Jenny Burman, "Masquerading Toronto through Caribana: Diasporic Carnival Meets the Sign "Music Ends Here","

in Transnational Yearnings Tourism, Migration, and the Diasporic City (Vancouver: UBC Press, 2010),130.

${ }^{165}$ Canada, City of Toronto, Council Liaison, Notice of Motion, by Joe Mihevc and Michael Thompson, May 11, 2010, 2, accessed May 16, 2018, https://www.toronto.ca/legdocs/mmis/2010/mm/bgrd/backgroundfile-29930.pdf.
} 
festival [held at a] staggering \$438 Million annually."166 Furthermore, Mihevc and Thompson noted that "\$313 Million"167 went into the economy of Toronto." Another "\$260 Million"168 contributed to "labour income"169 in the city, which translates to $5000^{170}$ jobs in the GTA ${ }^{171}$ and over "\$198 Million"172 is attributed to "total tax revenue."173

In addition, the Ipsos Reid report suggests that, "1.2 million" ${ }^{174}$ people attended the Festival in 2009, with "171,000 from the United States and a further 130,000 from the Caribbean, South America, Europe and Asia." 175 To fund festival operations, the FMC attains money from the "federal, municipal and provincial"176 levels of government, but as noted in 2010, the government funding "represents less than 1 percent of the total level of economic activities generated by the Festival" 177 and eight years later, there is no word if the percentage of funding have changed.

\section{1-METHODOLOGY}

\subsection{1-Research Strategy}

In early 2015 , months before I sat down to write my letter of intent in preparation for my application and subsequent entrance into the MFA in Documentary Media program at Ryerson University, I started researching the topic of Emancipation Day in Toronto. My fascination with this history and its celebrations spurred my interest in how Caribbean Canadians, or more broadly, how African Canadian Communal celebrations contribute to the formation of identity.

\footnotetext{
${ }^{166}$ Ibid.,2.

167 Ibid.

${ }^{168}$ Ibid.

169 Ibid.

${ }^{170}$ Ibid.

${ }^{171}$ GTA is the short form of the Greater Toronto Area.

172 Ibid.,2.

173 Ibid.,2.

174 "Scotiabank Caribana 2010 and Ipsos Reid Release Economic Impact Study Results," Canada NewsWire, April 27, 2010,2, accessed May 20, 2018, =https://search.proquest.com/docview/89276 044?accountid=13631.

175 Ibid.

${ }^{176}$ Ibid.,131.

${ }^{177}$ Canada, City of Toronto, Council Liaison, Notice of Motion, by Joe Mihevc and Michael Thompson, May 11, $2010,2$.
} 
My exploration grew in an interest into the role commonwealth status has on the formation of people of colour, especially when multiple generations share the complexity of colonized origins, as in the case of myself and my parents. I concluded that I wanted to dissect the representation of sovereign power in Canada and the Eurocentric iconography inherently intertwined within the notions of queenly imagery.

My investigation was not meant to be all-encompassing but to explore a specific fragment of the many elements contributing to the longstanding relationship between Emancipation Day and Toronto Caribbean Carnival. The research I conducted also adds to the conversation around Caribbean carnival, Blackness and Emancipation Day history, which various academics have long explored. Academics such as Natasha Henry, Lyndon Phillip, Cecil Foster, Jeff Henry, Jenny Burman, Charmaine Nelson, Afua Cooper, and Yaa Amoaba Gooden, to name a few. I reframe the conversation through the specificity of my argument and the combination of visual representation from present and past photographic images of carnival and Emancipation Day celebrations in Toronto.

Among the many research-creation projects exploring carnival, emancipation, or Mas' making traditions, I feel that my MRP is one of the only ones I have come across that has combined both current photo and audio documentation with archival reportage imagery, text, soundscape and poetry. Further, my MRP stands out because it investigates the notion of Queenliness in Caribbean carnival with a distinctly Canadian viewpoint. The uniqueness of using documentary practice to employ social and political arguments while also centralizing the twodimensional visualization of the images with the historical intricacy of the subject matter provides a new stream of investigation. This method places a stronger value on the pictorial 
representation of women in the history of both celebrations rather than solely having a textual focus.

My research also exposes the complexity of visualizing a transnational celebration ${ }^{178}$, such as carnival that heavily involves women of colour. The visual history I chose to explore is drenched in colonial, imperial, and institutional manipulation. This research-creation project forced me to take on the additional role of archivist, historian, and curator while at the same time, considering the scholarly practices that employ an anti-colonial, anti-racist, feminist particularly Black Canadian feminist's frameworks. These frameworks combat the embedded discriminatory and outlandish imposition, which constantly devalues images that contain women of colour, placing their cultural significates at the level of the spectacle.

\subsection{2-Positionality}

Michel-Rolph Trouillot accurately contextualizes the complexities of deconstructing historically dense subject matter that becomes complicated by the intertwined power structures which proceed them. He states: "the ultimate mark of power may be its invisibility; the ultimate challenge, the exposition of its roots." 179 This quote is relevant to my own research-creation practices, because as I have previously noted, being a young woman of colour born in Toronto, Canada and raised by parents who adhere to the many traditions upheld within a Caribbean/South American upbringing, I am constantly aware of the multilayered cultural frameworks that shape my understanding as well as the pre-established socio-political power structures at work in society.

\footnotetext{
${ }^{178}$ Migration and Transnationalism: Opportunities and Challenges, PDF, Geneva, Switzerland: International Organization for Migration (IOM), March 9-10, 2010.1- Transnationalism is defined by the International Organization for Migration (IOM) as “a different way of looking at migration: the transnational lens places the spotlight on the connections that migrants establish between countries."

${ }^{179}$ Michel-Rolph Trouillot, Preface to Silencing the Past: Power and the Production of History (Boston: Beacon Press, 1997), xix.
} 
In my current artistic practice, I create artworks that deal with the re-contextualization of African Canadian narratives. African Canadian history, a transnational, colonized, settler history, has a precedent of being undermined, erased, and rewritten to benefit the Eurocentric narratives which fill the minds of many Canadians today. The dissemination of this one-sided narrative is perpetuated by the various institutional powers which governed this stolen indigenous land. Further, those who benefit from this ahistorical narrative continue to hold their positions of power, fostering the perpetuation of the myth of diversity in all facets of Canadian life with little space for change. One of the ways I contribute in my artistic role is to pull apart the precedent that exists because by doing this, one starts to re-examine the power structures that exist and expose its roots.

\subsection{3-Limitations}

The main limitations of my master's research project were threefold. The first limitation was time, due to the temporal nature of carnival celebrations in Toronto, my access to the documentation of the 2017 King and Queen competition and the main research participants during the event was limited to the timeframe of the main event (August $3^{\text {rd }}$ from $3 \mathrm{pm}$ to midnight), the timeframe of each woman's performance in the designated stage area, and the weather conditions as it was an outdoor event without shelter.

The second limitation was the complexity of being an insider/outsider in the Toronto carnival celebrations. Prior to this project, my role in Toronto Caribbean Carnival was limited to being a spectator of the Mas'. I had no family ties to the carnival events, nor did I have any friends who participated in carnival as a bandleader, section leader, or masquerader. In other words, my familiarity with the cultural and historical significance of the events held during carnival in Toronto and the frequency with which I attended the carnival parade as a teen by no 
means contributed to the level of access I had to my main research participants. I had to constantly negotiate my position as a documentarian and MFA researcher because the spaces used to create Mas' centralize the communal, oral and participatory practice that has sustained carnival making.

The space and people are not always responsive to traditional academic research or institutions. Therefore, it takes constant communication and trust to establish a working relationship. These spaces uphold knowledge-sharing methods that are geared towards maintaining the creative, cultural and customer-oriented energy needed to thrive between the necessary stakeholders, which includes the Mas' bandleaders, Mas' section leaders, welders, designers, their respective volunteer assistants and the masqueraders, the participants of the Mas'. Lastly, the third limitation I had was legitimizing the historical intersectional complexity of my research argument when engaging my research participants. Many in the Caribbean Canadian carnival community were familiar with the relationship between carnival and Emancipation Day in the context of the Caribbean, but the connection it had in Canada was less known.

Therefore, I had to justify the duality of my research questions, which expanded beyond the surface of carnival performance and dived deep into the intertwined history of the events present. This caused some debate, so I had to constantly explain my reasoning. They would ask questions like, why was I choosing to document the Queen of the Bands instead of the King of the Bands? Or How does the relationship of Emancipation Day and carnival change when outside the Caribbean? I had to reassure some participants that their involvement with my project was not a strenuous or intimidating process and that their participation helped with the preservation of the culture. 


\subsection{4-The Role of the Archive}

The archive is one of the most significant ways communities access information to learn about past representations of their culture. In the case of my research, the archival images I have chosen to use in my exhibition demonstrated a visual thread that was not previously contextualized in relation to Queenliness, Carnival and Emancipation Day. The complexities of mining Caribbean Canadian narratives from archives are that their categorization and indexing may have culturally outdated descriptions or no description at all. This can constrict and discourage the researcher from accessing the material both contextually and physically. In Ontario, the archival material on the Caribbean Canadian community is not accessible through one institution or organization owned and operated by the community.

This leaves a void in the sourcing and finding of materials needed for scholarly research. In addition, through my research, I have determined that the preservation of archival narratives in the Caribbean Canadian community has mostly been textual in nature, preserved in cultural newspapers, peer-reviewed journals, biographical novels, opinion pieces, fictional narratives, and poetry anthologies. The ethnic/cultural community newspapers that I encountered during my archival research served as a starting point in locating the contextual framework of certain images, but, due to the incomplete nature of these volumes and the specificity of my research objectives, these newspapers have not significantly informed the visual research I conducted.

However, I am pleased that certain public institutions have facilitated the mindful archiving of these histories as a community resource. The reportage images that are central to my research have either been preserved in the private collections of the original photographer or have been lost to the boxes, hard drives, and family albums of people in the community. These personal collections have not been transferred to a public institution for research purposes. There is a 
strong need for the soliciting of this material so the archive does not stagnate and continues to grow.

My journey and physical relationship with the archive and staff started when I attended a symposium in late February 2017 entitled The Evolving Meaning of Blackness in Canada, an event that marked Black History Month. The symposium was spearheaded by the Jean Augustine Chair in Education, Community \& Diaspora, which operates within the Faculty of Education at York University in Toronto, Canada. The event was significant because it was the first time that the Chair had held such a celebration at York University. The Honourable Jean Augustine, Ontario's former Fairness Commissioner and the first Black woman member of parliament and cabinet minister in the Canadian federal government, was also in attendance.

During the event, the archivist for digital projects and outreach for York University's Clara Thomas Archive and Special Collections presented archival material from the Jean Augustine fond. This collection holds many years of documents and photographs which depict Augustine's involvement in community and government events. After the presentation, I had the pleasure of meeting the Honourable Augustine for the first time and had a brief conversation with her about my Master Research Project (MRP). She took the time to introduce me to the archivist for digital projects and outreach, suggesting that I explore her archival collection because it contained documentation of early Toronto Caribbean Carnival celebrations.

Prior to my introduction to the archivist, I had already cited the Clara Thomas Archive as a potential place to obtain archival documents, but this interaction fast-tracked the process. The subsequent communication I had with the archivist led to my first visit to the archives. York University's Clara Thomas Archives and Special Collections holds many fonds, including the Toronto Telegram fond. That collection contains " 830,000 negatives of photos 
taken for the newspaper during the period 1876 to $1971 . " 180$ The newspaper was initially called the "Evening Telegram"181 and was run by John Ross Robertson. ${ }^{182}$ The newspaper strived to highlight the "British connection in Canada," 183 and held a strong rivalry with the surviving "Toronto Star." 184 While exploring the archive, I started to notice the shift that has occurred in representation within early Toronto Caribbean Carnival and Emancipation day celebrations. So, I concluded that including these images as historically relevant artifacts contributes to the conversation I built around Queenliness.

On my initial visit to the archive, I prioritized both Jean Augustine and the Toronto Telegram fonds, as well as an out-of-print Caribbean Canadian community newspaper collection called Contrast. After looking through two giant binders containing the archives catalogues, I chose the content that I wanted to review and put in a request for the archival staff to pull 20 boxes of material. The process of finalizing the content I would use in my exhibition was not easy because each box contained hundreds of $35 \mathrm{~mm}$ negative film strips, categorized by year, date and event. These negatives were divided into a series of small brown envelopes, and I spent many hours looking through the packets I chose, carefully placing the negatives on a light table. Wearing archival gloves, I identified the images I would eventually use from the $35 \mathrm{~mm}$ negative film strips with a magnifying glass.

In addition, I decided to photograph the negatives in the order I encountered them. Then, I inverted each image in Adobe Photoshop, enlarging them to further see the details I missed on

\footnotetext{
${ }^{180}$ Rob Van Der Bliek, "Report on an Investigation to Digitize a Selection from the Toronto Telegram Photograph Collection," Clara Thomas Archives and Special Collections, November 2000, https://www.library.yorku.ca/web/archives/findingaids/telegram1/telegram-report-2001/.

181 "Guide to the Archival Resources of the Toronto Telegram at York University," Toronto Telegram Photographs, January 4, 2001, accessed June 16, 2018, https://www.library.yorku.ca/web/archives/finding-aids/telegram1/.

182 Ibid.

183 Ibid.

184 Ibid.
} 
my initial encounter with them. After this, I narrowed down my selection to only include the images from the Toronto Telegram Fonds and subsequently returned to the archive seven more times. The final images I selected have never been printed or displayed; therefore, they were not part of the public domain clearance that usually exempts researchers from paying a reproduction fee. This led to further paperwork that outlined the image's strict citation protocol and limited use, only allowing the display of these images for inclusion in my MFA exhibition.

This scanning process also held a fee per image clause, which I paid for out of pocket to obtain the high-quality scans of the images I needed, coming up to a total of $\$ 200$. The process also included the physical tagging of each image on the $35 \mathrm{~mm}$ film strip and noting each image's identification number, which appeared on the bottom of each strip. I also had to describe the key identifying elements in each image, such as the people or landscapes, to prevent the photos I did not want to be scanned from ending up in my final collection of digitalized content. In the end, I am glad I went through the process and was able to include archival images that reflect the cultural, social, and political arguments I explored for my MRP.

\subsection{5-Production Process}

I started my photographic production journey by contacting the bandleaders for each Mas' Band because they were my first point of communication when getting the opportunity to document the Queens of the Bands. If a Mas' band does not represent a queen, then she cannot compete in the King and Queen competition, so this initial step was very important. The bandleader (s) also establishes the theme for the band, usually designs the costume, or hires an appointed Mas' designer which can be the queen herself or her family and friends, oversee the sketches of the costume, and allocates space and tasks to section leaders, builders and welders. In the planning process, I made a contacts chart which consisted of each Mas' band's information, 
noting their warehouse (Mas'camp) location, bandleader name, band type and the overall costume theme.

As I previously mentioned, the 2017 King and Queen competition consisted of eleven bands, nine of which created a queen costume for the competition. The reason I chose to photographically document four Mas' band's is because I became aware of the Toronto Caribbean Carnival structure of band participation and categorization. Through my research, I concluded that the participation structure consisted of four Mas' band types (large, medium, small, and new). A large or A category band is a band that has more than 1000 masqueraders; a medium or B category band has more than 500; a small or C category band has 500 or less; and a "new band" is a Mas' band that has not participated in the carnival before so their numbers are yet to be determined and can vary in size. Although the participant numbers have little to do with the Queen of the band's performance, these numbers have a lot to do with the popularity of the Mas' bands in the community, which translates to supporters on competition day.

The Mas' bands categorization can also factor into the amount of sponsorship either monetary or in-kind they receive from organizations and businesses during and after the carnival season. Furthermore, the number of years a Mas' band has competed in the King and Queen competition, and the main parade can also affect their support from the community. During the competition, the queens are judged on several performance criteria that add up to a maximum score of a hundred points. This includes visual impact, which accounts for thirty points; authenticity, which accounts for ten points, creativity, which accounts for twenty points craftsmanship, which accounts for ten points; clarity of theme, which accounts for ten points; and finally, presentation, which accounts for twenty points. 
In scouting the queens, I wanted to make sure I documented a woman from each category. Usually, the big three or the largest Mas' bands would be discussed or photographed the most by the media and the public. In any case, I visited all the Mas' bands warehouses which are situated in various parts of Scarborough, Ontario, a suburban part of Toronto, east of the main downtown core. Historically, Scarborough's relationship with carnival has deep roots as there is a significant Caribbean Canadian population and two major carnival celebrations, the children's or kiddie's carnival and the opening church service. The most tedious aspect of the documentation process was scheduling meetings and adapting to the Mas' camp atmosphere. As much as carnival is a preservation of culture, it is also a business, and most of the costume registration and transactions take place in the Mas'camp space.

In addition, there is often a party atmosphere with food, drinks, and a lot of music, sometimes mellow and sometimes on full blast. This is important because to make a potential masquerader feel welcome and choose one band over the other the atmosphere must reflect the components of authentic Caribbean Mas' culture. During my visit to the Mas' camps, I would spend at least five hours or more interacting with the people and obtaining interviews or photographing the space. The Mas' camp atmosphere fluctuated from bustling to static, with the sound of welding, hammering and beads a constant element of the space. One day I would be speaking with a bandleader, and someone would ask their opinion on a design or request their assistance on costume registration, and another day I could walk in and have a sit-down conversation without interruption.

As I got acquainted with the Mas' bands, I acquired various levels of access to the environment. I started by documenting the Mas' camps and interviewing the bandleaders and queens for each band. I made a different set of questions for the bandleaders and a different set 
for the queens. When I interviewed each queen, I took a headshot of them so that I could have an image of them outside of their queen costume. I also did this because I wanted to use the warehouse space as a backdrop, but this changed during the editing process (See 2.1.6 PostProduction Process).

Regarding equipment, I used a Canon EOS 5D Mark III DSLR camera with various Canon lenses and my personal Canon Speedlite 420EX flash and H4n Pro Zoom recorder. On the day of the King and Queen competition, I had to be mindful of the weather because the stadium where the event was held was open air, so just in case, I bought rain covers for all the equipment and a wind cover for my Zoom recorder. On the day of the King and Queen competition, I quickly observed the schedule of each woman I was documenting, noting when she would be performing and also averaging when she would enter and exit the stage area.

I arrived at the stadium around 4:00 pm and could not get behind-the-scenes access until 5:30 pm. In the event that this would happen, I bought VIP passes for $\$ 200$, so I stayed in the VIP area and spoke with others attending the event before locating each Mas' band and their respective queens backstage. Some of the Mas' bands were stricter about their pre-performance setup and rituals, while others had a more relaxed vibe before stage time. I documented behind the stage area as the bands rolled in their costumes, material and metal structures.

I also documented the theatrical production entitled $\mathrm{Ol}^{\prime}$ Time Carnival that put on a folklore-based show before the main King and Queen competition started. The presentation was produced by Cajuca Mas Arts Producers Toronto and included Caribbean folk music and old Mas' characters. The traditional costumes in the pre-show presentation reference a "type of 
Masquerade portrayed during J'ouvert deriving from the French term "jour ouvert (open day, or daybreak)." 185

J'ouvert is typified by characters such as "Jab Molassis, Jab jabs, Blue Devils, Baby Dolls and Dame Lorraine's." 186 Their theatrical presentation also included Pierrot Grenade, African drummers, Moko Jumbies, Stick fighters, Midnight Robbers, a narrator and calypsonian. Before the main Queens performed, there was the junior King and Queen, who were the young masqueraders who won the King and Queen Competition for youth. Then there were the female and male individual costumes, mini versions of the larger King and Queen costumes, and then the Queen of the band performed, followed by the final performance of the Kings of the Band.

The Queens that agreed to be documented at the competition included Michelle Reyes, who represented Saldenah Mas’ K Club- (Saldenah Carnival) and performed under the theme Celebration Time. Emilsa Sealy, who represented Durham Mas and performed under the theme Canboulay! Dis Is Mas'. Deidra Amow, who represented Sunlime Canada and performed under the theme Illusions of Reality and lastly, Ayanna Lee-Rivears, who represented Venom Carnival and performed under the theme Kang Ka Tang: When De Iron Roars.

Saldenah Mas’ K Club- (Saldenah Carnival), led by bandleader Louis Saldenah selected Reyes to wear a queen costume called Celebration of a Cultural Composition. Durham Mas, led by bandleader Jerrol Augustine selected Sealy to wear a queen costume called La Dame EDame Lorraine. Sunlime Canada, led by bandleader Dwayne Gunness selected Amow to wear a queen costume called Journey to Valhalla and Venom Carnival led by bandleaders Hayden

\footnotetext{
185 Garth L. Green, Trinidad Carnival: The Cultural Politics of a Transnational Festival (Bloomington: Indiana University Press, 2007),229.

186 Philip W. Scher, Carnival and the Formation of a Caribbean Transnation (Gainesville: University Press of Florida, 2004), 185 .
} 
Joseph and Aneil Persad selected Lee-Rivears to wear a queen costume called A Canal Fish Story.

Each woman only had five minutes on stage to highlight their moves and queen costumes; therefore, I had to be ready to capture each woman and be mindful of when she entered and exited the stage. A temporary white tile floor covered almost half the stadium. There were fences that created various sections for the Mas' bands and the audience, and there were also large screens on each side for those in the audience who had paid for bleacher seats instead of the premium VIP seats closer to the stage. Many other photographers and news outlets were covering the performances, so I had to negotiate my proximity to the stage while also obtaining a media pass accreditation for the King and Queen showcase to allow me to gain backstage access. Overall, I got a wide variety of shots and successfully documented each woman's performance.

\subsubsection{Post-Production Process}

The first point of departure in the post-production process was organizing the large amount of photographic and audio documentation I acquired during my summer production. The initial numbers included over 300 images taken at the 2017 King and Queen competition and over 500 images taken at the four Mas'camp's. What was helpful in my process was abiding by the four bands categories, which I've previously noted as large, medium, small, and new. I first organized the photos taken at the Mas' camps by band type, then I categorized the images by event and location and then further created folders for each of my main research participants.

I divided the batch of images I took at the King and Queen competition by day and night, which was reflective of the event's progression from midafternoon to midnight. This strategy also made it easier for me to find the themes that began to emerge in the images. Then, I divided the shots of each woman's queen costumes and the preparation before and after her performance. 
As I previously mentioned, I had various levels of access during the event, and, therefore, the collection of images I took for each woman varied according to the amount of access each woman provided at the event.

After categorizing the photos, I started to narrow them down, looking at the narrative or the amount of contextual representation of the event. It was important that all final images I selected from the King and Queen competition reflected the nature of the event because the Canadian audience's familiarity with this carnival event outside of my target audience was less guaranteed. Regarding the images I took of the Mas' camps, I started to notice that many patterns emerged, such as the representation of the Mas' camp volunteers or section leaders in the space and the repetition of individual costumes displayed on manikins.

There were also banners containing the Mas' bands costume theme, and their respective community affiliation and sponsorship logo's. All these elements added to my arguments about the nature of Toronto carnival and the specificity of the environment which Mas' is made, but through the editing process, I decided that these images would not make the final cut for my MFA exhibition and served as a source of background information in my overall documentation process. The final edit consisted of removing the background information from the portraits I took of each woman and replacing it with a clean white background, making the woman stand out more.

Finally, I completed a colour correction and light balancing on the backstage shots of the King and Queen competition, the twenty archival photographs and the performance shots with slight cropping to bring forward the women's queen costumes. I completed a decent amount of restoration on the scanned copies of the final archival images I paid for because the files I received from the technical archivist had not been retouched or restored, some scrapes, creasing 
and age spots and discoloration from the $35 \mathrm{~mm}$ film were still present on the images before I removed them. The editing of the audio interviews I conducted was an eye-opening experience that was informative but also time-consuming. Using Adobe Audition, I edited the interviews I conducted with each Queen, but I chose to leave my voice out of the final excerpts to centralize the women's voices. Overall, Through the editing process, I strived to highlight the women's most unique responses to reflect the duality of their perspectives on carnival and Queenliness in Toronto.

\subsection{7-Gallery Installation}

My exploration of past and present histories, contributed to the various creative approaches I employed in the execution of my gallery exhibition, which included portraiture, audio interviews, archival materials, text, and poetic narration. The planning and installation process in the days leading up to the exhibition opening became a significant part of my MFA journey, as I curated and installed all the elements. The main contents of my exhibition included thirty photographs, four audio players containing excerpts of each woman's interview conducted in the Mas'camp, an additional audio player with my poetic narrative discussing the intertwined relationship of Emancipation Day and Toronto Caribbean Carnival, a cluster of wood text (See Appendix F) and a custom white vinyl artist statement (See Appendix N) which I designed and paid for to fit the gallery's specific space and wall dimensions.

The gallery I utilized for the exhibition, named Areej Art gallery is between 800 and 1000 square feet, is long and rectangular and can be defined as a storefront style gallery. There is one glass front window and entrance; therefore, I placed the archival content on one side of the gallery and the Queen of the Bands images I took on the other side. Twenty of the photographs in the exhibition were sourced from the $35 \mathrm{~mm}$ photo negatives I obtained from my archival 
research at the Clara Thomas Archive, York University. The other ten photos were from my documentation of the women during the King and Queen competition.

My photographic documentation consists of four black and white portraits representing the four main queens, dressed in casual daily attire. To frame the portraits, I used $16 \times 20$ gold frames that I bought from a custom frame store. Each frame contained white mats, but I replaced them with black mats to make the portraits of the women stand out in their casual attire, beyond their queen costume images. Beside each woman's portrait was an MP3 player, which I bought specifically for the gallery exhibition and encased each one in a wood box which I built, painted with white acrylic paint and lacquered.

I also bought large stereo headphones to accompany each MP3 player and placed excerpts of the interviews I conducted with each woman in the Mas'camp on each one of the audio players. These audio excerpts were set on a loop so that the audience did not have to interact directly with the MP3 players while listening to them. Adjacent to the women's black and white portraits were the images of each woman in their Queen costumes on a separate section of the same wall. I placed these images in black frames with matching mats, and to curate a cohesive look; I used the same black frames and mats that contained the archival photos.

The start and end of the women's queen costume photos were anchored with event scenes I took at the King and Queen competition throughout the day. Both anchoring images depicted a man in costume on stilts, which is called the pierrot grenade. This traditional old Mas' character appeared in the pre-show portion of the King and Queen competition. I used the images of the pierrot grenade walking towards and away from the camera to comment on the cyclical nature of the competition and the historical influence of traditional Mas' on contemporary carnival celebrations. 
The text portion of my installation contains over 100 individual wood letters, which I sanded, painted, and lacquered. I chose a combination of eighteen words and dates to include in the wall text installation piece, which greeted gallery attendees as they entered the exhibition. These keywords in the wall installation referenced emancipation and carnival and represented something tangible that the audience could refer to when learning about the interlaced history I presented in the gallery space.

The wood text also referred to the way keywords are utilized in academic papers and research databases. Furthermore, I wanted something in the gallery space that commented on the intensity of creative labour and the materiality of making, which is essential to Mas'. These words reference the concepts present in my research and photographic documentation and introduced terms that both challenge and complement the notion of Queenliness. The poem I wrote and recorded is an important additional element in the installation because I wanted to present my voice as an artist-scholar and highlight my perspective in crafting the narrative framework of these histories in the gallery space.

\subsection{8-Target Audience and Location}

The target audience for my MRP was mixed because I wanted to educate the general public about the historical importance of Emancipation Day in Toronto and its relationship to Toronto Carnival and sovereign power structures. For clarification, there were two specific subgroups that I targeted amongst the general Canadian public. The first is women, specifically women who define themselves as part of the African Canadian or Caribbean community. These communities are most affected by the historical narrative and contemporary manifestation of Emancipation Day celebrations through the context of my research.

The next group I targeted was my generation, those young adults who inherit this festival 
and are performing under the historical precedents it brings, especially in the case of Toronto's Caribbean Carnival's parade. Toronto Caribbean Carnival is a space where young people, particularly of African or Caribbean heritage, recognize the party atmosphere of the events and the relationship it holds to the Caribbean Canadian community, but may not recognize the historical/political underpinnings that contributed to the parade's existence in Toronto. By experiencing my photographic exploration of this topic in the gallery space, I want young people to redefine their role and contributions when bringing forward historical events that are rarely discussed in the mainstream narratives of Canadian history.

In addition, to aid the access of exhibition for my target audiences, I chose to rent an east end gallery space for $\$ 600$ for the week of the exhibition instead of renting a downtown gallery space because I wanted the Toronto Caribbean Carnival community to have close access to the MFA exhibition during the height of their production season as a majority of the Mas' camps were located in the east end of the city.

\subsection{9-Research Results}

The motivation behind each woman's participation in Toronto Caribbean Carnival's king and Queen competition centers around three key themes, family, cultural preservation, and knowledge sharing. There were also different levels of agency in their performance and participation in the overall process of being a queen among the group of women I documented and interviewed. Some women significantly contributed to the making and designing of the queen costume, while others were only involved on the day of the competition. The involvement of the Queens family became a key component of the women's success because of the monetary and physical commitment of being a Queen in Toronto Caribbean Carnival. 
The quality of the embellishments on the costume as well as the material used in making the structure has a strong association with the amount of money spent by the queen if she is tasked with taking on the full responsibility of the cost. Ultimately, cost effects the woman's ability to participate at the level needed to compete and win the overall title, so the families and Mas' band's financial support becomes vital to the success of the women's participation in competition. In addition, depending on the women's involvement in the design of the queen costume, there will need to be a certain level of understanding from the women's family regarding the significant amount of time commitment required to build and prepare for the competition.

This is because most women in the competition must balance work and the care of their family members as well as other domestic responsibilities in addition to their participation in carnival. Cultural preservation is another theme that emerged in my research. The historical relationship of carnival and the implication of generational involvement in the festivities have major links to preservation of cultural traditions and become a central factor to the queen's involvement in the festival.

Finally, knowledge sharing became critical factor that contributed to women preforming as a queen. The queens shared a certain amount of camaraderie, alongside their competitiveness. With this came a willingness to share their experiences, which was most visible in the exchange the queens had with younger participants of the carnival. These younger carnival participants have some experience in Toronto Caribbean Carnival but most have never participated in the King and Queen competition before. 


\section{1-DOCUMENTARY RELEVANCE}

When examining documentary relevance for my Master's Research Project (MRP), I started to look at artists who dealt with the themes I explored in my research. Then I examined how these artists used various aspects of documentary practice to create their work. Most of the artists rarely defined themselves as documentarians, but their chosen media fit within the various documentary traditions I have read about and researched. This includes documentary reenactment, and the relationship documentary works have with the archive. The following three artists will be discussed in relation to the documentary relevance of this MRP, and they include Melinda Mollineaux, Leah Gordon and Camille Turner.

\subsection{1-Melinda Mollineaux}

The first photo series I will discuss is Cadboro Bay: Index to an Incomplete History by Canadian artist Melinda Mollineaux. Mollineaux photo series has great relevance to my documentary production and exploration of the archive. Mollineaux's images (See Appendix A) were made using the process of pinhole photography, where she documented a place on Vancouver Island where African Canadians "held Emancipation Day picnics in the late nineteenth and early twentieth century."187

The photo series no longer exists as an exhibited work, but it was preserved and contextualized by scholar Andrea Fatona in her essay, "In the Presence of Absence: Invisibility, Black Canadian History” and Melinda Mollineaux's Pinhole Photography. Fatona discusses Mollineaux's images and suggests that her photographic work "forces the spectator to negotiate the erasure of visual evidence of Blackness from official historical narratives by effectively

\footnotetext{
${ }^{187}$ Andrea M. Fatona, "In the Presence of Absence: : Invisibility, Black Canadian History”, and Melinda Mollineaux’s Pinhole Photography," Canadian Journal of Communication 31, no. 1 (2006),230.
} 
portraying absence using the otherworldly aesthetic of pinhole photography." 188 Fatona goes on to discuss the technical aspects of Mollineaux's work and states that the photographs in the Cadboro Bay series are not "merely snapshots of time and space, but are material reminders, mementos of Mollineaux's conscious insertion of her own Black body into the imagined picnic taking place in the space of Cadboro Bay."189

There were two themes in Mollineaux's work that I felt related to the context of my own documentation, the reimagining of the Black body and the reintegration of Black identity within Canadian historical narratives. Mollineaux’s examination of imagined and historicized Black bodies, more importantly to my research, Black female bodies within the framework of Canadian history, is important and needs to be addressed more within documentary photography practice. Centralizing Black bodies of the past through documentary photography can be a way to compensate for the exclusion or minimizing of Black people in Canada, particularly in the context of female identity, which has bared the brunt of racism and sexism. Secondly, Mollineaux's work brings awareness to the multi-layered importance of space and the notion of ownership in communal celebrations that involves Black, Caribbean and African Canadian communities.

Mollineaux's photos are reflective of the natural essence of the space documented on the island, there are no people, and we do not see a trace of the artist's body. Fatona suggests that at first glance, the images appear to be bare, but when you look closer, there are "graphite inscriptions... symbols similar to those found on maps." ${ }^{190}$ In addition to this, there is an accompanying textual narrative, which makes these photographs come alive. The poetic text that

\footnotetext{
188 Ibid.,227.

189 Ibid.,231.

190 Ibid.,230
} 
accompanied Mollineaux's photographs was created through action-oriented events and research material she found in historical records held at the "British Columbia Provincial Archives."191 Short statements such as, "John Craven Jones predicted rain," "J.J. Moore spoke in tongues," "Elizabeth Leonard realized her betrayal," and "Rebecca Gibbs tended fires."192

These short statements placed the artist in the space as a spectator and asked us to do the same. It conveys the idea that Mollineaux's experienced the events in such detail that she noticed the smallest gesture, re-inscribing important aspects of the narrative that would be lost in the larger historical importance of the event. This gives a certain amount of agency back to the people who contributed to the experience of an event centred around the community. The historical compensation for the absence of Black bodies and Mollineaux's technique intrigued me because she made me reflect on my role as an artist and the agency I give to my subjects and the audience when documenting a history that is minimized by the larger Canadian historical narrative.

\subsection{2-Leah Gordon}

Another photographic series that strongly represents Black bodies and Caribbean Carnival festivities is Kanaval by British multimedia artist Leah Gordon (See Appendix B). Her photographic series deals with the materiality, history, and Mas' making of carnival. In the essay Performance of Possibilities scholar, Myron M. Beasley describes Gordon's images of the carnival in Jacmel, Haiti, which she completed over sixteen years, ${ }^{193}$ as "performance

\footnotetext{
191 Ibid.,231.

192 Ibid.

${ }^{193}$ Leah Gordon, "Kanaval", accessed October 23, 2017, http://www.leahgordon.co.uk/index.php/project/kanaval/.
} 
ethnography,"194 and holding the space between "documentation, public memory and the phantasmic theatre of the historic imagination." 195

Beasley precisely points to what Gordon's photography signifies to me: the ability to live in the space between ethnography and documentary, but her role as an outsider or a non-Haitian is only cushioned by the years she spent documenting and researching the carnival performance in Haiti. Her work stands out because it reverses the carnival aesthetic and focuses on composition and materiality as well as Black masculinity. In addition, her images are striking due to their black and white nature. This is unique for carnival images because, in the context of contemporary carnival, the documentation of festivities has predominantly showcased an exuberant amount of colour. In an essay written by Gordon, she describes her experience in Haiti's carnival and suggests that:

Jacmel (carnival) is lightyears away from the sanitized, corporate-sponsored, and tourist-driven carnivals around the world. There appears to be no set time, route, or parade. One can wander a seemingly deserted street, then turn a corner to find a group of cardboard masked solicitors and judges, ... performing a play based on a nineteenthcentury French novel. ${ }^{196}$

The strength of Gordon's images relies on the nature of Haiti's carnival, which rejects the glamour of the more famed bikini Mas' widely favoured in Brazilian, Trinidadian, and even North American carnivals, such as Toronto Caribbean Carnival. The loss of mass-produced and imported embellishment leaves room for a new emergence of spectacle that is raw, real, and far removed from the touristic gaze. These images play with the roots of carnival costuming and creation, a history that is connected to the folklore and early traditions of Caribbean emancipatory carnival celebrations. The images speak to the struggle and sacrifice for freedom

\footnotetext{
${ }^{194}$ Myron Beasley, "The Performance of Possibilities," accessed October 23, 2017, http://myronbeasley.com/research/haiti/theperformance-of-possibilities/.

195 Ibid.

${ }_{196}$ Leah Gordon, “Kanaval,” Radical History Review, 115 (2013): 170, doi:10.1215/01636545-

1724760. http://resolver.scholarsportal.info/resolve/01636545/v2013i0115/169_k.
} 
that has become central in carnival's narrative. Stories that are now reserved for the recounted traditions of old Mas', which refer to the type of masquerade portrayed during J'ouvert, a "celebration that begins around two o'clock in the morning, where people come out into the streets (and parade) in paint, mud and oil." 197

Overall, the photos point to a history of carnival that favours the assemblage. When the enslaved in the Caribbean became seemingly emancipated, they only had access to found objects and materials. Through this, they turned trash into treasure and repurposed it to make social commentary through performance. Leah Gordon's photo series clearly adds to the conversation and highlights the various approaches that other artists have taken that preceded or differed from my photo documentation of carnival. The connection between my work and Gordon's is that she is willing to move beyond the surface of the carnival spectacle and dive into depicting the historical narrative that the spectacle of beauty tends to hide.

\subsection{3-Camille Turner}

The third and final series I will discuss is the work of Jamaican-born, ${ }^{198}$ Canadian artist Camille Turner. Her photo series Hometown Queen, ${ }^{199}$ and the performance persona depicted in the series Miss Canadiana (See Appendix C) demonstrate the complexities of dealing with "doubly diasporized"200 identity as wells as the notion of Queenliness being abject to the Black body within the Canadian landscape.

\footnotetext{
${ }^{197}$ Garth L. Green, Trinidad Carnival: The Cultural Politics of a Transnational Festival (Bloomington: Indiana University Press, 2007),229.

198 Alison Cooley, "Camille Turner," The Canadian Encyclopedia, January 14, 2016, accessed May 29, 2018, http://www.thecanadianencyclopedia.ca/en/article/camille-turner/.

${ }^{199}$ Camille Turner, "Miss Canadiana Confronts the Mythologies of Nationhood and the $\mathrm{Im} /$ possibility of African Diaspora Memory in Toronto," Caribbean Intransit Art Journal 1, no. 2 (March 2012): 12, accessed May 28, 2018, $\mathrm{https}$ ://issuu.com/caribbeanintransit/docs/issue 2 caribbean intransit location_and caribbean/52.

${ }^{200}$ Charmaine Nelson, Ebony Roots, Northern Soil: Perspectives on Blackness in Canada (Newcastle: Cambridge Scholars, 2011), 17.
} 
In her photo series, Turner wears a red dress, tiara, and a pageant sash that reads Miss

Canadiana. She stands in front of an industrial background that depicts Hamilton, Ontario.

Turner suggests that she created the series to "re-write a personal history,"201 acknowledging the "complex relationship" 202 with her hometown. She explains:

The Hamilton I grew up in was a proud, hard-working steel town with a no-nonsense attitude. On the one hand, I admire this city's fierce resistance to the influence of nearby sprawling full-of-itself Toronto. On the other hand, growing up there I witnessed and experienced many incidents of blatant bigotry. I couldn't wait to get away from Hamilton when I was young but now I realize that this complex city made me the person I am today - always looking beneath the surface and recognizing the irony in everything around me. ${ }^{203}$

The photo series was exhibited in 2010, but the persona traces back to $2002 .{ }^{204}$ Turner has performed Miss Canadiana in various places such as the UK, Germany, Senegal, Australia, Cuba, Jamaica and Mexico, ${ }^{205}$ and she states that in her performance art persona, "my body, as a representative of Canadian heritage, is surprising only because Blackness is perceived as foreign in Canada." ${ }^{206}$ Turner uses tropes of pageantry and characteristics of Queenliness in her performance as Miss Canadiana to re-contextualize the historical narratives of African Canadians through walking tours and formal meet and greets. Her photo series and performance art persona intersect with my MRP on various levels. It highlights the complexity of performing as a queen while being a woman of colour holding Caribbean heritage. The series also investigates the notion of sovereign power and its role in validating Canadian narratives and, finally, the importance of place and identity in the Canadian landscape.

\footnotetext{
${ }^{201}$ Camille Turner, "Camille Turner," Camille Turner RSS, Accessed May 28, 2018, http://camilleturner.com/project/misscanadiana/.

${ }^{202}$ Ibid.

203 Ibid.

204 Ibid.

205 Ibid.

206 Ibid.
} 


\section{CONCLUSION}

In conclusion, I have observed through my research that Caribbean women of colour, particularly Afro-Caribbean women, use Queenliness as a mechanism of resistance to the socialpolitical implication of society. As scholar M. Cynthia Oliver notes in her book Queen of the Virgins: Pageantry and Black Womanhood in the Caribbean, "in the European imaginary, any association between royalty and womanhood was in no way connected with Black female subjects." ${ }^{207}$ Oliver continues by suggesting that because of the institution of slavery and the demands on the Black female body to endure "animal-like work regimes (as well as) punishments, ${ }^{208}$ Queenliness created the space for Black women to reconstruct their persona in a complex hegemonic system. She adds, "the survival response, the propensity to resist, was the stuff of the Black woman's reconstitution and involved the figure of the queen first as leader, (and) as a motivator of the people who mobilized crowds. Such actions later came to represent female power and attractiveness in carnival festivities." ${ }^{209}$

When discussing Caribbean representation and power, scholar Lia Bascomb adds to Oliver's argument by suggesting that the notion or trope of Queenliness acts as a "diasporic resource, which allows (a woman) to negotiate diverse standards of respectability, femininity, and sensuality while offering herself as a representation of (Her given) locality (and) the wider Caribbean region." 210 Throughout my MRP research and creative journey, I have reaffirmed that during the process of exposing historical roots, it is important also to find the space to recontextualize the pre-established historical narratives that exist so that the information one

\footnotetext{
${ }^{207}$ M. Cynthia Oliver, Queen of the Virgins: Pageantry and Black Womanhood in the Caribbean (Jackson: University Press of Mississippi, 2009), 21.

208 Ibid., 24.

${ }^{209}$ Ibid.

${ }^{210}$ Lia T. Bascomb, "I'm So Proud to Be Your Queen": Alison Hinds and Queenliness as a Diasporic Resource," Meridians 13, no. 1 (2015): 78, doi:10.2979/meridians.13.1.78.
} 
gathers in the process of research-creation does not perish during its exposure but thrives when replanted and distributed. The effectiveness of documentary photography in this project dwells in its power to highlight various forms of erasure which impede the complex and intermingled relationship of carnival and emancipation in Canada and the Caribbean. By analyzing the photographic image through documentary principles, we can create a space to visualize the impact of complex colonial histories that can be compromised by our fascination with the spectacle. 


\section{APPENDICES}

\section{Appendix A}

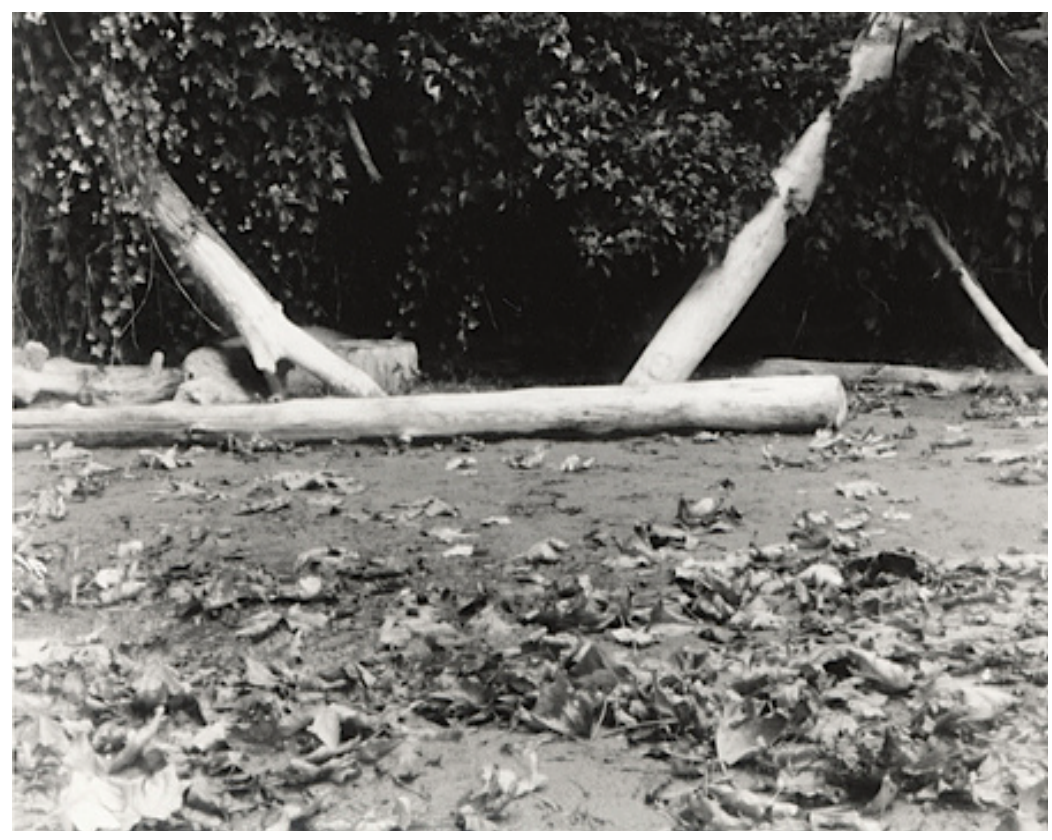

Figure A-1 Untitled, Cadboro Bay: Index to an Incomplete History, (C Melinda Mollineaux, 1998

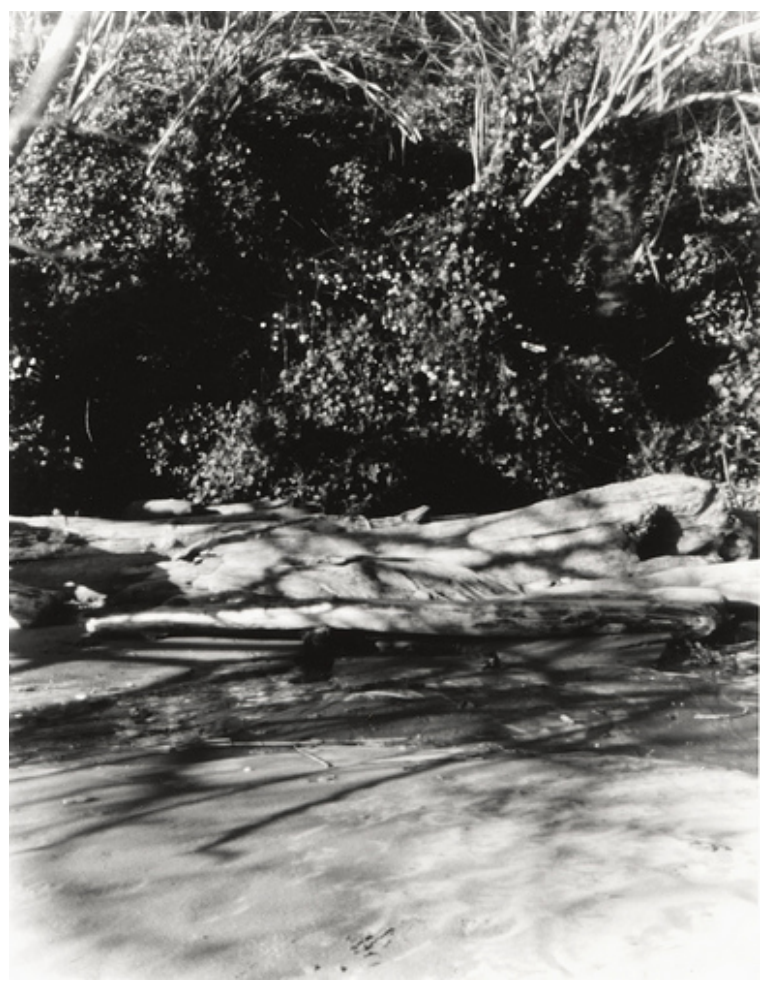

Figure A-2 Untitled, Cadboro Bay: Index to an Incomplete History, @ Melinda Mollineaux, 1998 


\section{Appendix B}

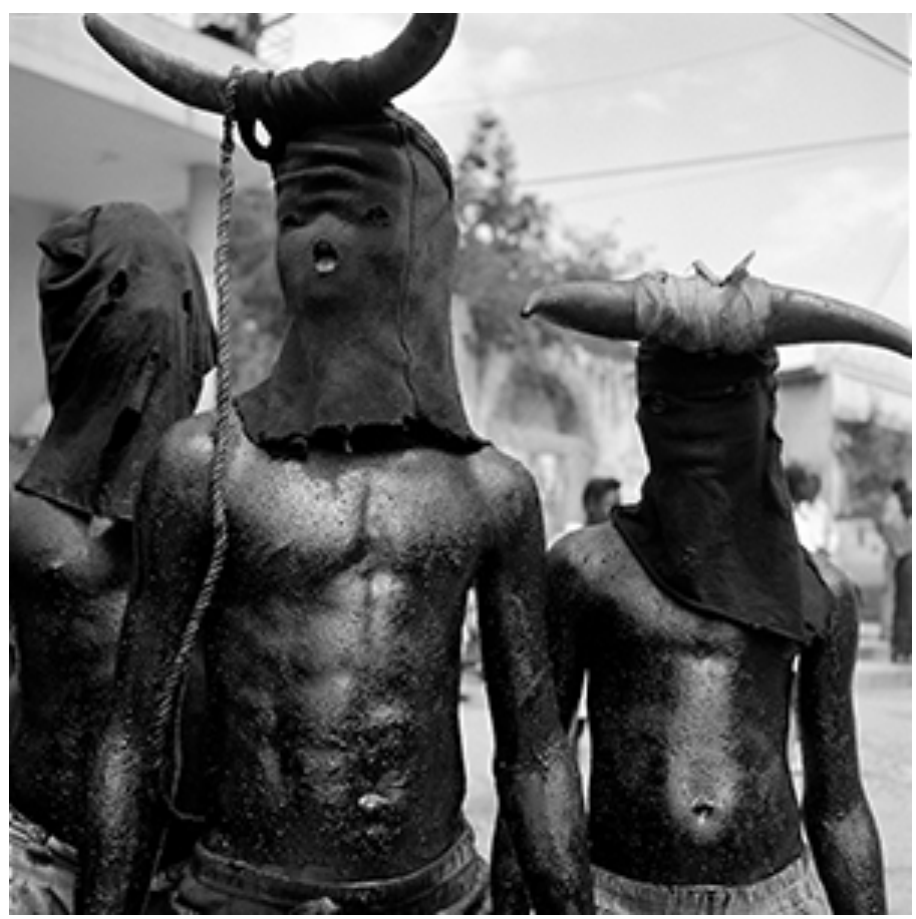

Figure B-1 Untitled, from the photo series Kanaval, (C) Leah Gordon,1993-2008

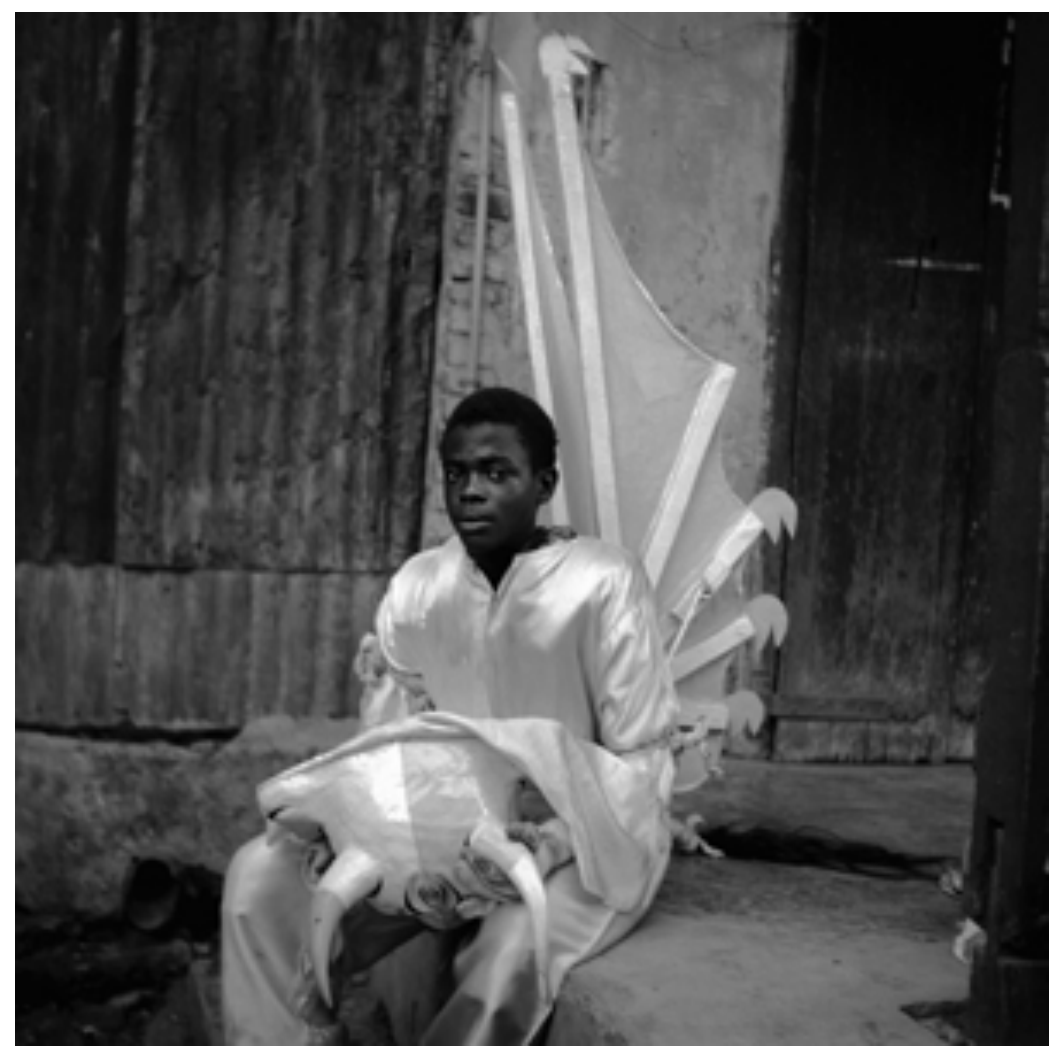

Figure B-2 Untitled, from the photo series Kanaval,(C) Leah Gordon,1993-2008 


\section{Appendix C}

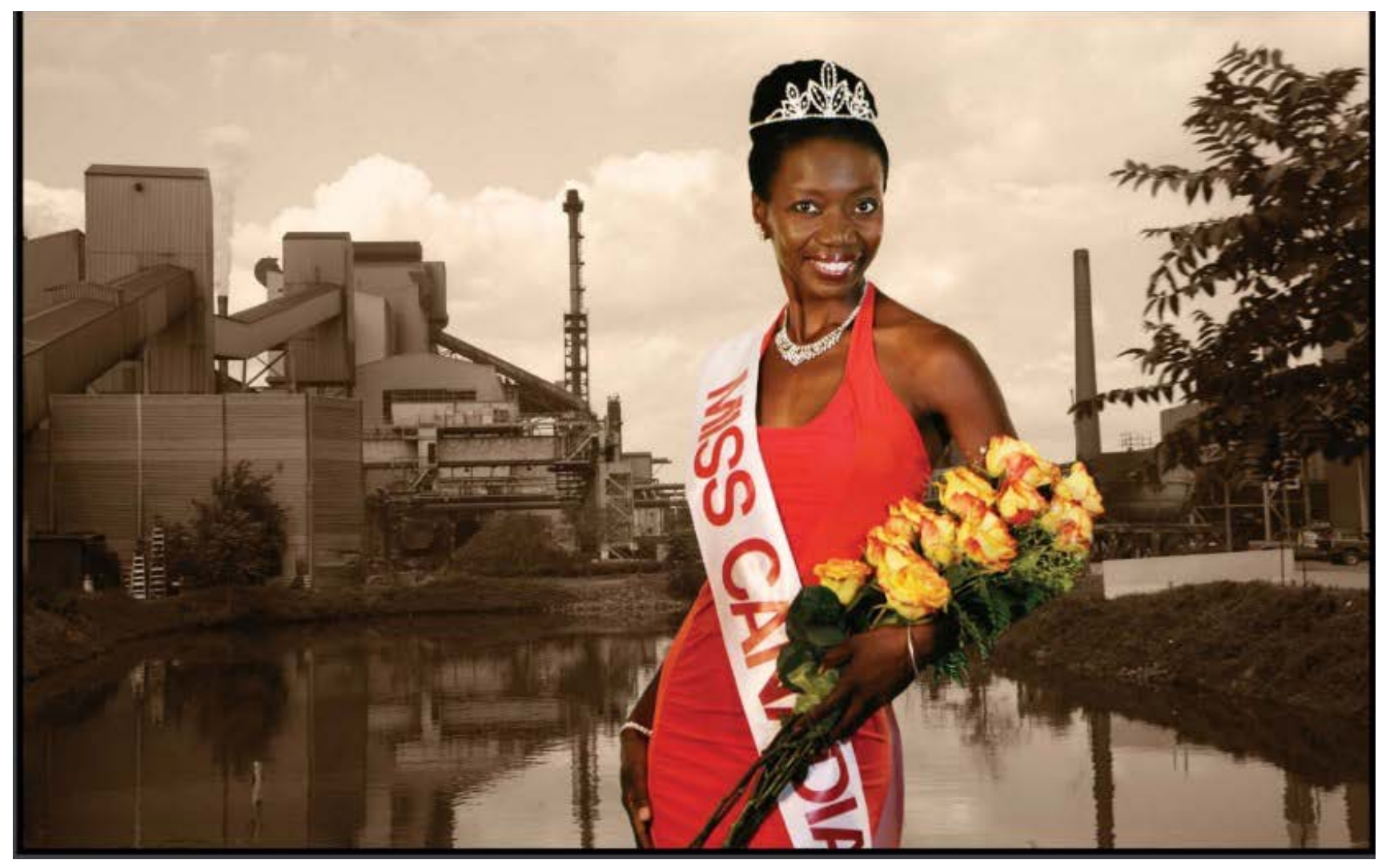

Figure C-Untitled, from the series Hometown Queen, C Camille Turner, 2010, Photographers: Barb Greczny and Patrick Ellard. Digital compositing: Camille Turner 


\section{Appendix D}

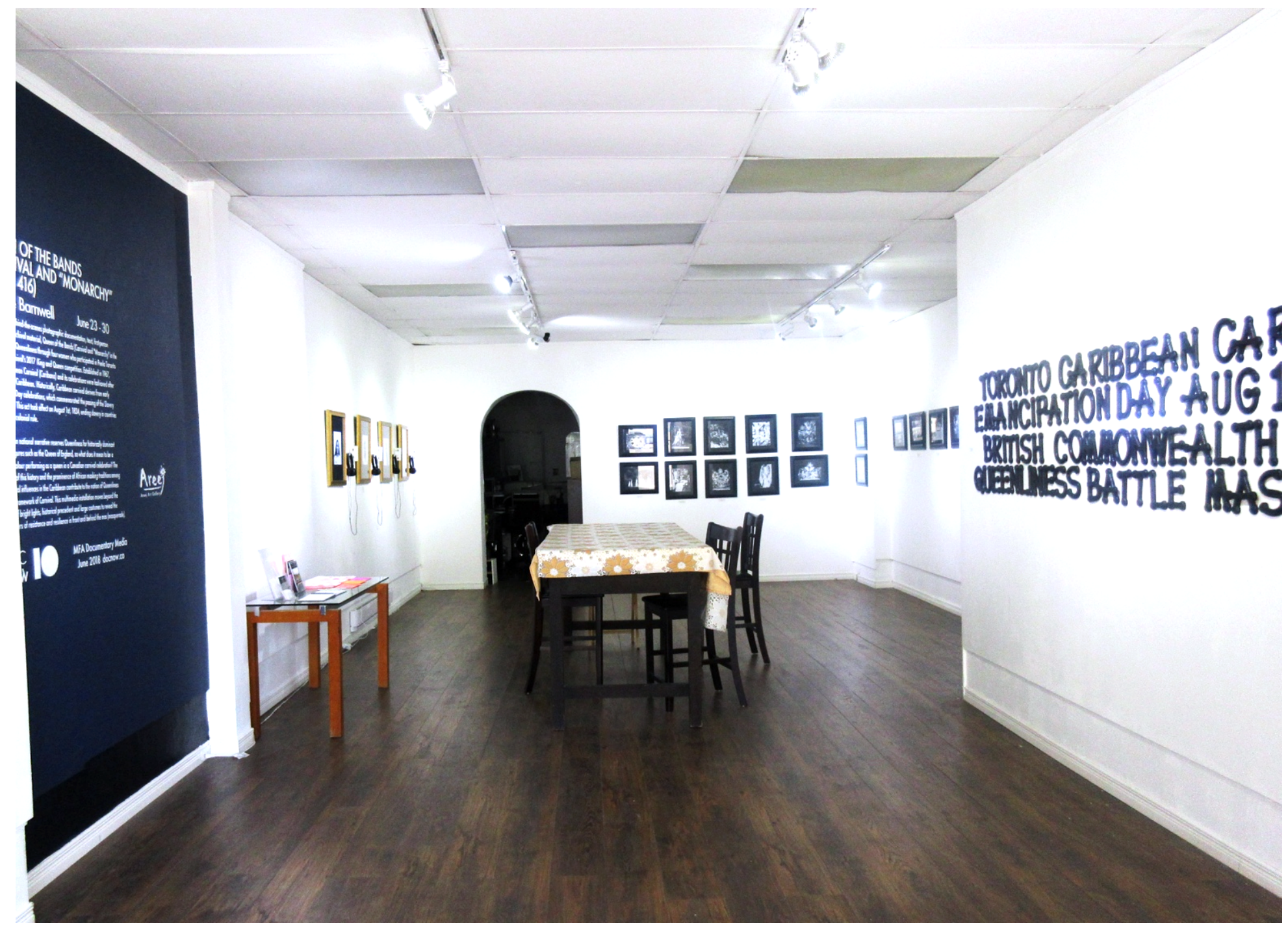

Figure D-Queen of the Bands: Carnival and "Monarchy" in the 416, Gallery Installation view, (C) Chante Barnwell,2018 


\section{Appendix E}

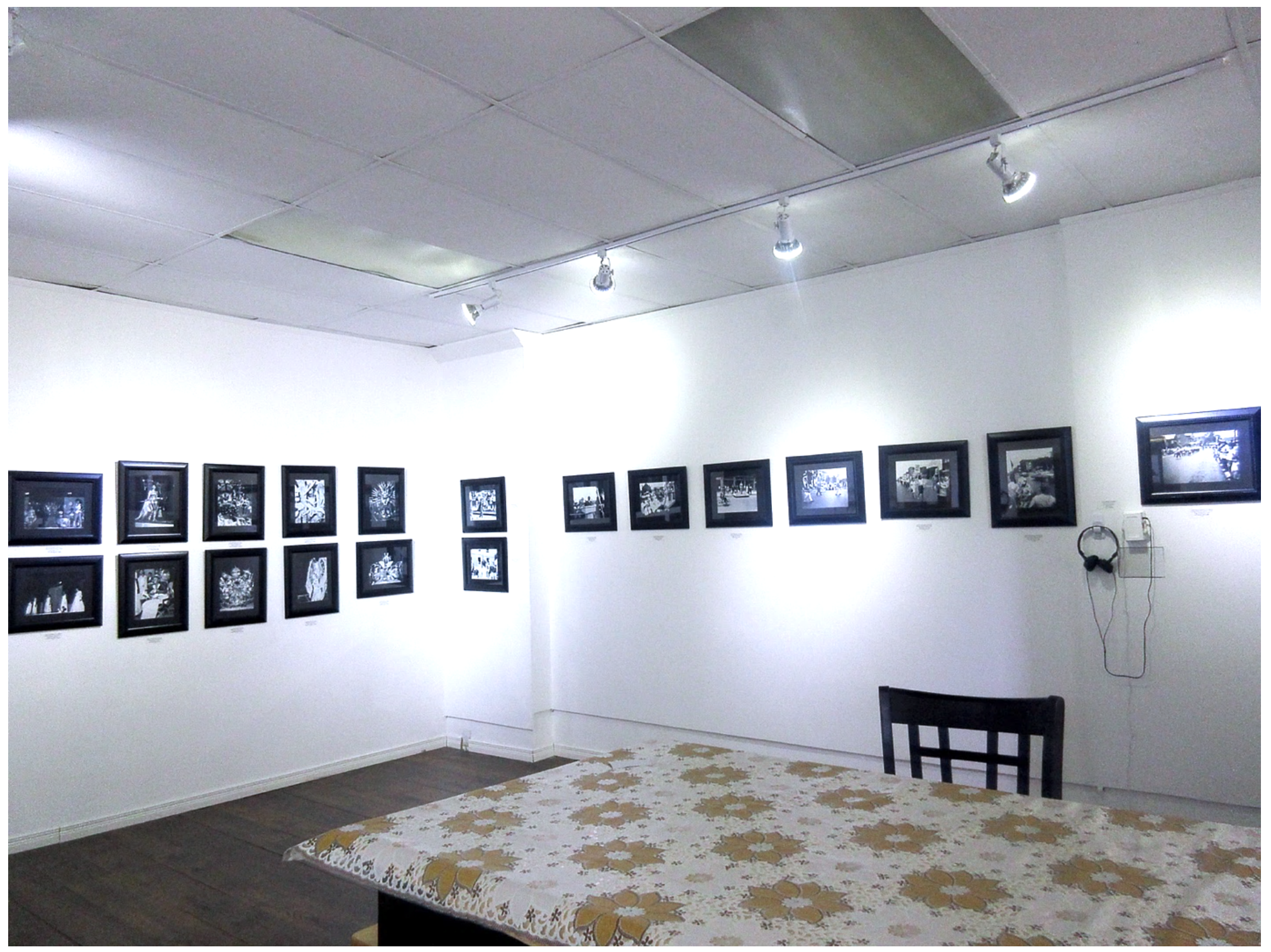

Figure E-Queen of the Bands: Carnival and "Monarchy" in the 416, Gallery Installation view of Archival Images from Toronto Telegram, Clara Thomas Archives \& Special Collections, (C) Chante Barnwell, 2018 
Appendix F

\section{TORONTO CARIBBEAN CARNIVAL 2017 WOMEN EMANCIPATION DAY AUG 183450 YEARS 1967 BRITISH COMMONWEALTH MONARCHY CANADA QUEENLINESS BATTLE MAS BANDS FLASHYFETE}

Figure F-Queen of the Bands: Carnival and "Monarchy" in the 416,Gallery Installation view of Keywords, Text piece, wood, black acrylic paint, varnish, (C Chante Barnwell,2018 


\section{Appendix G}

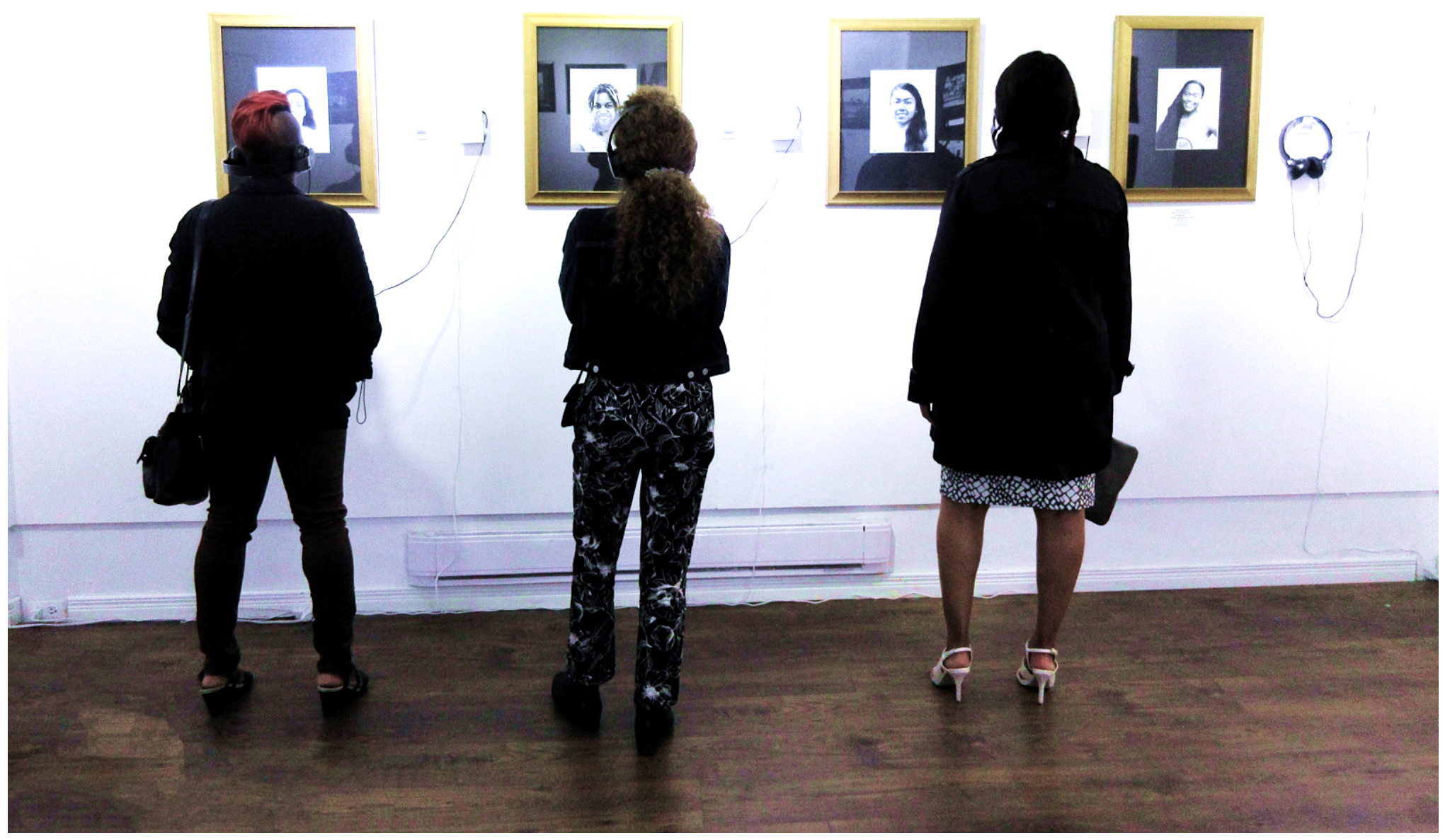

Figure G-Queen of the Bands: Carnival and "Monarchy" in the 416, Gallery Installation view of the Queen Portraits (C) Chante Barnwell,2018 


\section{Appendix H}

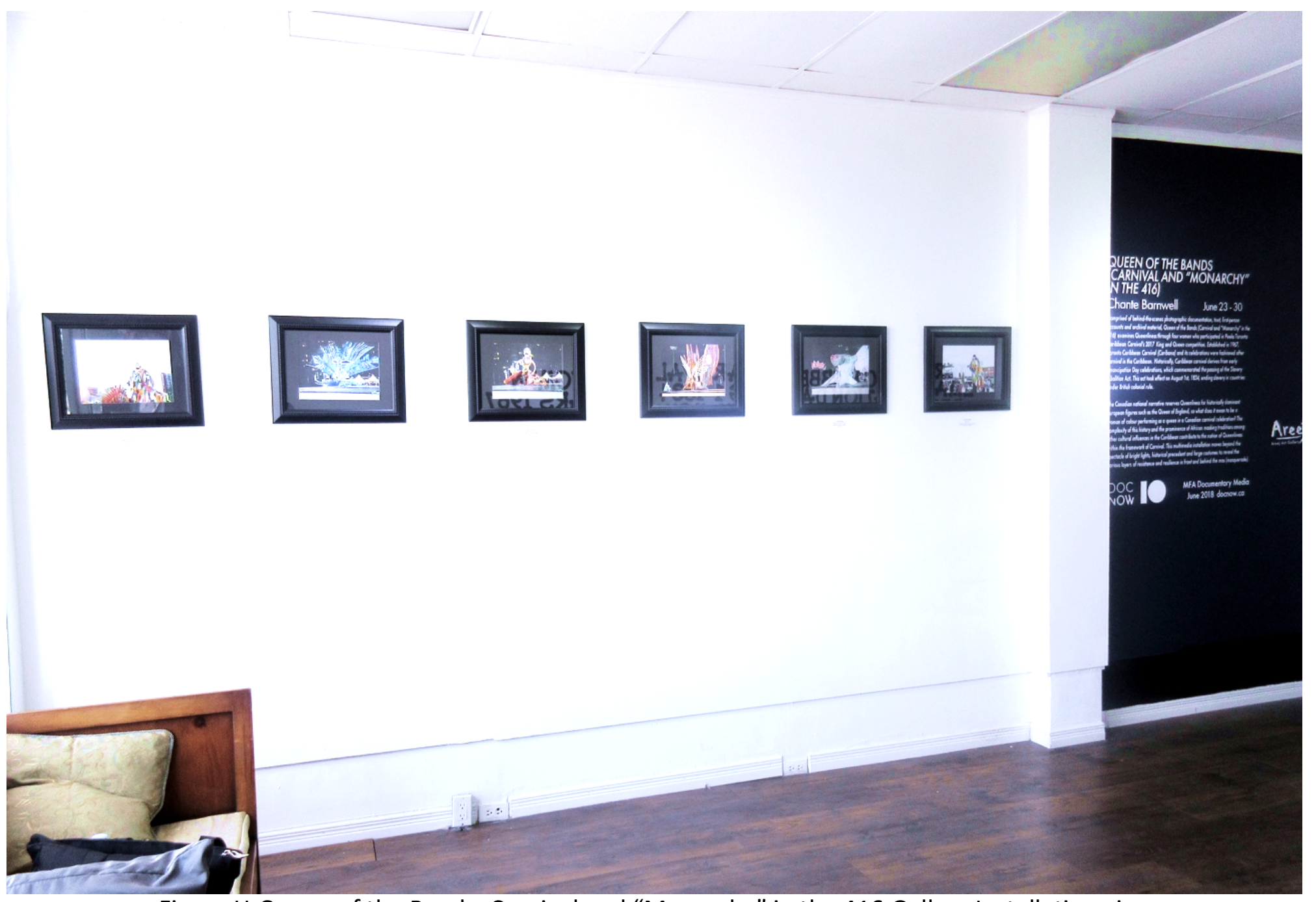

Figure H-Queen of the Bands: Carnival and "Monarchy" in the 416,Gallery Installation view of the King and Queen Carnival Competition Day (C Chante Barnwell,2018 


\begin{abstract}
Appendix I
Queen of The Bands: Summary of Research Participants List of research participants in order of Mas' band size Research Participant 1
\end{abstract}

Name: Michelle Reyes

Cultural Heritage: Trinidadian

Prior Years as Queen of the Band: Eight

Mas' band: Saldenah Mas' K Club- (Saldenah Carnival)

Masquerade Category: Large Band

Bandleader: Louis Saldenah

Theme: Celebration Time

Title of Queen's Portrayal: Celebration of a Cultural Composition

\title{
Research Participant 2
}

Name: Emilsa Sealy

Cultural Heritage: Panamanian

Prior Years as Queen of the Band: Zero

Mas’ Band: Durham Mas

Masquerade Category: Medium Band

Bandleader: Jerrol Augustine

Theme: Canboulay! Dis Is Mas'

Title of Queen's Portrayal: La Dame E -Dame Lorraine 


\section{Appendix J}

Queen of The Bands: Summary of Research Participants

\section{Research Participant 3}

Name: Deidra Amow

Cultural Heritage: Trinidadian

Prior Years as Queen of the Band: Zero

Mas’ Band: Sunlime Canada

Masquerade Category: Small

Bandleader: Dwayne Gunness

Theme: Illusions of Reality

Title of Queen's Portrayal: Journey to Valhalla

\section{Research Participant 4}

Name: Ayanna Lee-Rivears

Cultural Heritage: Trinidadian

Prior Years as Queen of the Band: Zero

Mas’ Band: Venom Carnival

Masquerade Category: New Band

Bandleader: Hayden Joseph/Aneil Persad

Theme: Kang Ka Tang: When De Iron Roars

Title of Queen's Portrayal: A Canal Fish Story 


\title{
Appendix K
}

\author{
Summary of Interview Questions for Main Research Participants \\ Questions written by Chante Barnwell
}

1. State your name and the name of the band.

2. What is the theme for 2017 Peeks Toronto Caribbean Carnival?

3. Please describe your role as Queen of the Bands.

4. What would you say is your occupation outside of participating in Mas'?

5. What inspired you to play Mas'?

6. How many years have you been playing the queen in the King and Queen competition?

7. What will your queen costume be depicting this year?

8. Prior to playing mas in this band, what is your previous experience in carnival and Mas' making?

9. What is your cultural heritage or background?

10. How would you define your racial identity?

11. What are the difficulties in performing as the Queen of your Mas' band?

12. How does the queen's theme relate to your overall band theme?

13. How have your strategies evolved over the years, when performing in the King and Queen competition?

14. Do you feel playing big Mas' differs from playing as an individual masquerader?

15. Do you feel that the carnival spectacle plays a major role in defining a woman of Caribbean heritage in Canadian society?

16. How does the term queen represent to you when playing Mas'?

17. How do you prepare for your performance?

18. If you could change anything about the King and Queen competition what would it be and why?

19. Who designs the singular performance outfit?

20. Who is the designer of your Queen costume?

21. How long has the designer worked with your Mas' band

22. What is the estimated cost of the queen costume, who is paying for the costume?

23. What preparation goes into making the queen costume, and what materials are involved?

24. What usually happens on the day of the King and Queen competition?

25. What are your objectives for this year's festival as we celebrate the 50th anniversary? 


\section{Appendix L}

\section{List of Archival Reportage Images}

Twenty archival image labels as displayed in the MFA exhibition

1. York University Libraries, Clara Thomas Archives \& Special Collections, Toronto Telegram fonds, ASC41545.

2. York University Libraries, Clara Thomas Archives \& Special Collections, Toronto Telegram fonds, ASC41549

3. York University Libraries, Clara Thomas Archives \& Special Collections, Toronto Telegram fonds, ASC41552

4. York University Libraries, Clara Thomas Archives \& Special Collections, Toronto Telegram fonds, ASC41563

5. York University Libraries, Clara Thomas Archives \& Special Collections, Toronto Telegram fonds, ASC41568

6. York University Libraries, Clara Thomas Archives \& Special Collections, Toronto Telegram fonds, ASC41573

7. York University Libraries, Clara Thomas Archives \& Special Collections, Toronto Telegram fonds, ASC41574

8. York University Libraries, Clara Thomas Archives \& Special Collections, Toronto Telegram fonds, ASC41578

9. York University Libraries, Clara Thomas Archives \& Special Collections, Toronto Telegram fonds, ASC41581

10. York University Libraries, Clara Thomas Archives \& Special Collections, Toronto Telegram fonds, ASC41586

11. York University Libraries, Clara Thomas Archives \& Special Collections, Toronto Telegram fonds, ASC41518

12. York University Libraries, Clara Thomas Archives \& Special Collections, Toronto Telegram fonds, ASC41519

13. York University Libraries, Clara Thomas Archives \& Special Collections, Toronto Telegram fonds, ASC41520

14. York University Libraries, Clara Thomas Archives \& Special Collections, Toronto Telegram fonds, ASC41521

15. York University Libraries, Clara Thomas Archives \& Special Collections, Toronto Telegram fonds, ASC41522

16. York University Libraries, Clara Thomas Archives \& Special Collections, Toronto Telegram fonds, ASC41523

17. York University Libraries, Clara Thomas Archives \& Special Collections, Toronto Telegram fonds, ASC41524

18. York University Libraries, Clara Thomas Archives \& Special Collections, Toronto Telegram fonds, ASC41525

19. York University Libraries, Clara Thomas Archives \& Special Collections, Toronto Telegram fonds, ASC41526

20. York University Libraries, Clara Thomas Archives \& Special Collections, Toronto Telegram fonds, ASC4152 


\section{Appendix M}

\section{Emancipation! Carnival!}

Transcription of the narrative poetry included in the MFA exhibition

Written, recorded, edited and performed by Chante Barnwell

Emancipation! Carnival! Two words forever intertwined, two words connected to my presence as a woman of colour in this land.

Emancipation marks the abolition of slavery and commemoration of those enslaved.

Emancipation Day is a commemorative event that has been celebrated in Ontario for 183 years. Caribbean Carnival signifies the re-imagination of the past and the creative reframing of the present.

Toronto Caribbean Carnival has been celebrated for 50 years with the grand parade held around the anniversary of Emancipation Day, August $1^{\text {st }}$.

Canada is a country declared as the true north strong and free.

A country that has projected a national narrative of peace, unity and inclusion, but this projection constantly contributes to the erasure of other narratives.

Narratives that define my visibility in this land.

Narratives of people who were considered cargo in the province of Ontario until the abolishment of slavery in 1833. African Canadian Women, Black Women who have suffered extensively in the erasure of their narrative.

The erasure of narratives such as the one that involves Chloe Cooley, a young Black woman enslaved, sold, beaten and dragged across a Niagara River, never to be seen again? Have you seen the slave advertisement placed for Peggy Pompadour and her 15-year-old son Jupiter? Read an advertisement made by Canadian politician Peter Russell in 1806 who proposed the sale of the 41-year-old mother of three, who was enslaved in downtown Toronto. 
Did you know that the first female editor in North America, Mary Ann Shadd, ran The

Provincial Freeman, an anti-slavery newspaper printed on King street?

As part of the commonwealth, a designation that marks the status of former countries in the British Empire, we held a front row seat to the injustice of slavery.

To be a citizen of Canada, one takes allegiance to the Queen of England, so how does the representation of Queenliness change when a woman of colour is considered a queen?

How do the standers of Queenliness change?

what happens to our national narrative when separated from a dominant Eurocentric narrative?

Can the queenly qualities of respectability and honour be translated to the Black body, the racialized body, women of colour?

In my quest to answer these questions, I discovered women whose representation of Queenliness comes from their participation in carnival.

Starting in the Seventeen hundred on slave plantations of the Caribbean islands when women mocked their aristocratic plantation owners act of resistance and self-preservation translated into acts of Queenliness. These women knew what the persona of Queenliness afforded them as they were entrenched in the swamps of slavery and the birth of freedom.

It afforded them time to reaffirm their value, their vibrancy and most importantly, their visibility.

The notion of Queenliness transcended the days of emancipation and found itself in the creation of carnival themed beauty pageants such as Miss Caribana and finally in Toronto Caribbean Carnival's King and Queen competition, where women of different ages, gender, and ethnicity vie for Queen of the Bands the head female masquerader in carnival. It that the relationship between Emancipation and Carnival hold that signifies the complexity of Queenliness. 
Appendix N

Artist Statement

MFA exhibition wall text, originally printed on white vinyl

Written by Chante Barnwell

Adobe Illustrator layout designed by Chante Barnwell

\section{QUEEN OF THE BANDS (CARNIVAL AND "MONARCHY"
(N THE 416) Chante Barnwell June 23 - 30}

Comprised of behind-the-scenes photographic documentation, text, first-person accounts and archival material, Queen of the Bands (Carnival and "Monarchy" in the 416) examines Queenliness through four women who participated in Peeks Toronto Caribbean Carnival's 2017 King and Queen competition. Established in 1967, Toronto Caribbean Carnival (Caribana) and its celebrations were fashioned after carnival in the Caribbean. Historically, Caribbean carnival derives from early Emancipation Day celebrations, which commemorated the passing of the Slavery Abolition Act. This act took effect on August 1st, 1834, ending slavery in countries under British colonial rule.

The Canadian national narrative reserves Queenliness for historically dominant European figures such as the Queen of England, so what does it mean to be a woman of colour performing as a queen in a Canadian carnival celebration? The complexity of this history and the prominence of African masking traditions among other cultural influences in the Caribbean contribute to the notion of Queenliness within the framework of Carnival. This multimedia installation moves beyond the spectacle of bright lights, historical precedent and large costumes to reveal the various layers of resistance and resilience in front and behind the mas (masquerade).
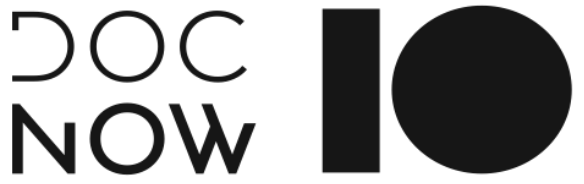

\section{MFA Documentary Media June 2018 docnow.ca}




\section{Appendix O}

\section{Keywords}

List of words used in the wood text wall installation which was a part of the MFA exhibition

1. Toronto

2. Caribbean

3. Carnival

4. 2017

5. Women

6. Emancipation Day

7. Aug 1,1834

8. 50 Years

9. 1967

10. British

11. Commonwealth

12. Monarchy

13. Canada

14. Queenliness

15. Battle

16. Mas Bands

17. Flashy

18. Fête 


\section{BIBLIOGRAPHY}

“Afua Cooper.” Dalhousie News. Accessed May 24, 2018.

https://www.dal.ca/faculty/arts/sociology-social-anthropology/faculty-staff/ourfaculty/afua-cooper.html.

Banks, Kenneth J. Chasing Empire Across the Sea: Communications and the State in the French Atlantic, 1713-1763. Montreal: McGill-Queens University Press, 2006.

Bascomb, Lia T. “'I'm So Proud to Be Your Queen': Alison Hinds and Queenliness as a Diasporic Resource." Meridians 13, no. 1 (2015): 78-102. doi:10.2979/meridians.13.1.78.

Beasley, Myron. "The Performance of Possibilities." Myron M. Beasley. Accessed May 31, 2018. http://myronbeasley.com/research/haiti/the-performance-of-possibilities.

Bilby, Kenneth M. "Surviving Secularization: Masking the Spirit in the Jankunu (John Canoe) Festivals of the Caribbean." New West Indian Guide / Nieuwe West-Indische Gids 84, no. 3-4 (2010): 179-223. Accessed July 5, 2018. doi:10.1163/13822373-90002440.

Bliek, Rob Van Der. "Report on an Investigation to Digitize a Selection from the Toronto Telegram Photograph Collection." Clara Thomas Archives and Special Collections. November 2000. Accessed December 17, 2017. https://www.library.yorku.ca/web/archives/finding-aids/telegram1/telegram-report-2001 Braganza, Chantal. "Why We Decided to Capitalize Black, Aboriginal and Indigenous." TVO. October 07, 2016. Accessed June 18, 2018. https:/tvo.org/article/current-affairs/why-we-decided-to-capitalize-black-aboriginal-andindigenous-. 
Burman, Jenny. "Masquerading Toronto through Caribana: Diasporic Carnival Meets the Sign "Music Ends Here"." In Transnational Yearnings Tourism, Migration, and the Diasporic City, 129-52. Vancouver: UBC Press, 2010.

Canada. City of Toronto. Council Liaison. Notice of Motion. By Joe Mihevc and Michael Thompson. May 11, 2010. Accessed May 16, 2018. https://www.toronto.ca/legdocs/mmis/2010/mm/bgrd/backgroundfile-29930.pdf.

Canada. Ontario Legislative Assembly of Ontario debates, $4^{\text {th }}$ December 2008 (Mr. Ted Arnott, PC). http://www.ontla.on.ca/house-proceedings/transcripts/files_pdf/04-DEC2008_L099.pdf

Cooley, Alison. "Camille Turner." The Canadian Encyclopedia. January 14, 2016. Accessed May 29, 2018. http://www.thecanadianencyclopedia.ca/en/article/camilleturner/.

Cooper, Afua. "Constructing Black Women's Historical Knowledge." Atlantis: Critical Studies in Gender, Culture \& Social Justice 25, no. 1 (2000): 39-50. Accessed June 15, 2018. http://journals.msvu.ca/index.php/atlantis/article/view/1544.

Cooper, Afua. Foreword to Natasha L. Henry, Emancipation Day: Celebrating Freedom in Canada,9-14. Toronto: Natural Heritage Books, 2010.

"Declare August 1st as Emancipation Day in Canada." The Royal Commonwealth Society of Canada -Emancipation Day. Accessed June 16,2018.http://www.rcs.ca/emancipation_day.html.

"Definition of queenly." Queenly definition and meaning | Collins English Dictionary. Accessed October 29, 2017. https://www.collinsdictionary.com/us/dictionary/english/queenly. 
Dewis, Adeola Patricia. "Carnival Performance Aesthetics: Trinidad Carnival and Art Making in the Diaspora." Ph.D. diss., Cardiff University, 2014.

Donovan, Ken. "Slavery and Freedom in Atlantic Canada's African Diaspora:

Introduction." Acadiensis 43, no. 1 (2014): 109-15.

http://www.jstor.org/stable/24329578.

"E-1289 (National Day)." Paper Petitions - Guide for The Public. Accessed June 16, 2018. https://petitions.ourcommons.ca/en/Petition/Details?Petition=e-1289.

Elder, J. D. "Cannes Brûlées." TDR 42, no. 3 (Autumn 1998): 38-43. 2006.

Accessed July 9, 2018. doi:doi:10.1162/105420498760308436.

Ember, Melvin, and Carol R. Ember. Encyclopedia of Diasporas: Immigrant and Refugee Cultures around the World. New York: Springer, 2005.

Fatona, Andrea M. "In the Presence of Absence: Melinda Mollineaux's Pinhole Photography." Canadian Journal of Communication 31, no. 1 (2006): 227-237.

Foster, Cecil, and Chris Schwarz. Caribana, The Greatest Celebration. Toronto: Ballantine Books, 1995.

Gordon, Leah. "Kanaval."http://www.leahgordon.co.uk/index.php/project/kanaval/. Accessed December $18^{\text {th }}, 2017$.

Gordon, Leah. “Kanaval.” Radical History Review 115 (2013): 169-183.

doi:10.1215/016365451724760. http://resolver.scholarsportal.info/resolve/01636545/v2013i0115/169_k. 
"Guide to the Archival Resources of the Toronto Telegram at York University." Toronto Telegram Photographs. January 4, 2001. Accessed June 16, 2018. https://www.library.yorku.ca/web/archives/finding-aids/telegram1/.

Henry, L. Natasha, Emancipation Day: Celebrating Freedom in Canada. Toronto: Natural Heritage Books, 2010.

Ipsos Reid. Culture. "Canadians See the Future of the Monarchy in Canada, Falling Head Over H.” News release, July 13, 2011. Ipsos News \& Polls. Accessed May 26, 2018. https://www.ipsos.com/en-ca/canadians-see-future-monarchy-canada-falling-head-overheels-wills-and-kate.

Ipsos Reid. Culture. "While Queen Lauded and People Warm to Prince Charles, Country Split on Future of Monarchy in Canada.” News release, June 12, 2012. Ipsos News \& Polls. Accessed May 26, 2018. https://www.ipsos.com/en-ca/while-queen-lauded-and-peoplewarm-prince-charles-country-split-future-monarchy-canada.

Lee, Maureen Elgersman. Unyielding Spirits: Black Women and Slavery in Early Canada and Jamaica. New York: Garland Pub., 1999.

Lewis, Claudio. “Introducing: Miss Caribana '77.” Contrast Newspaper, July 28 ${ }^{\text {th }}, 1977$. Mann, Jatinder. "The Evolution of Commonwealth Citizenship, 1945-1948 in Canada, Britain and Australia." Commonwealth \& Comparative Politics 50, no. 3 (July 2012): 293-313. doi:10.1080/14662043.2012.692923.

McCabe, Nora. "Miss Caribana 71' Is Crowned-Costume Goes up in Flames but Wins First Prize." Toronto Daily Star (Toronto, Ontario, Canada), July 31, 1971, What's Happening sec.

Merchant, David, and Paul Rich. "Canada and the Commonwealth." American Behavioral 
Scientist 47, no. 10 (2004): 1319-1328. doi:10.1177/0002764204264257.

"Message - OBHS President." Ontario Black History - Home. Accessed June 15, 2018. http://www.Blackhistorysociety.ca/message---obhs-president.html.

Minshall, Peter. “To Play Mas”." Caribbean Quarterly 45, no. 2-3 (1999): 30-35. doi:10.1080/00086495.1999.11829613.

Mollineaux, Melinda. "Random notes Cadboro Bay: Index to an incomplete history." Accessed February 7, 2006. http://www.smallaxe.net/sxspace/works_melinda.html.

Nelson, Charmaine. Ebony Roots, Northern Soil: Perspectives on Blackness in Canada. Newcastle: Cambridge Scholars, 2011.

Oliver, Cynthia M. Queen of the Virgins: Pageantry and Black Womanhood in the Caribbean. Jackson: University Press of Mississippi, 2009.

“On This Day.” About | Historica Canada. Accessed May 23, 2018. https://www.historicacanada.ca/about.

Peeks Toronto Caribbean Carnival Festival. Marketing \& Public Relations. "King \& Queen Showcase to Celebrate 50 Years of Carnival Arts." News release, July 31, 2017. Toronto Caribbean Carnival. Accessed July 5, 2018. https:/torontocarnival.ca/. Peeks Toronto Caribbean Carnival. Media. "New Name, Expanded Programming for Carnival's 50th Year." News release, June 1, 2017. Toronto Caribbean Carnival. Accessed July 6, 2018. https://torontocarnival.ca/.

Peeks Toronto Caribbean Carnival. Media. "Peeks Toronto Caribbean Carnival's King \& Queen Competition Most Spectacular Show Under the Stars Followed by North America's Largest Pan Alive." News release, June 06, 2017. Toronto Caribbean Carnival. Accessed July 6, 2018. https://torontocarnival.ca/. 
Phillip, Lyndon. "Reading Caribana 1997: Black Youth, Puff Daddy, Style, and Diaspora Transformations." In Trinidad Carnival: The Cultural Politics of a Transnational Festival, edited by Philip W. Scher and Garth L. Green, 102-135. Bloomington: Indiana University Press, 2007.

Taucar, Jacqueline. "Making Mas: TruDynasty Carnival Takes Josephine Baker to the Caribbean Carnival." Canadian Theatre Review 152, no. 1 (Fall 2012): 19-24. Accessed July 5, 2018. doi:10.1353/ctr.2012.0078.

Tettey, Wisdom J., and Korbla P. Puplampu, eds. The African Diaspora in Canada: Negotiating Identity and Belonging. Calgary: University of Calgary Press, 2005. Accessed May 27, 2018.https://dspace.ucalgary.ca/bitstream/handle/1880/48644/UofCPress_AfricanDiaspor a_2005.pdf?sequence $=5$.

Tharps, Lori L. "The Case for Black With a Capital B." The New York Times. November 19, 2014. Accessed June 18, 2018. https://www.nytimes.com/2014/11/19/opinion/the-casefor-black-with-a-capital-b.html?smid=tw-share\&_r=1.

Trouillot, Michel-Rolph, Silencing the Past: Power and the Production of History. Boston: Beacon Press, 1997.

Turner, Camille. "Camille Turner." Camille Turner RSS. Accessed May 28, 2018. http://camilleturner.com/project/miss-canadiana/.

Scher, Philip W. Carnival and The Formation of a Caribbean Transnation. Gainesville, FL: University Press of Florida, 2004. 
Scher, Philip W. and Green, Garth L. Trinidad Carnival: The Cultural Politics of a Transnational Festival. Bloomington: Indiana University Press, 2007.

"Scotiabank Caribana 2010 and Ipsos Reid Release Economic Impact Study Results." Canada NewsWire, April 27, 2010. Accessed May 20, 2018. https://search.proquest.com/docview/89276 044?accountid=13631.

"Sign the Petition." Change.org. Accessed June 16, 2018.

https://www.change.org/p/justin-trudeau-make-august-1st-emancipationday-in-Canada.

Stevens, Karolee. "Carnival: Fighting Oppression with Celebration." Totem: The University of Western Ontario Journal of Anthropology, 14th ser., 2, no. 1 (Spring 1995): 65-68. Accessed July 4, 2018. https://ir.lib.uwo.ca/totem/vol2/iss1/14.

Walcott, Rinaldo. "Emerging Diaspora Consciousness among African-Canadians in Toronto." In Encyclopedia of Diasporas: Immigrant and Refugee Cultures around the World, edited by Melvin Ember and Carol R. Ember, 438-45. New York: Springer, 2005. 